\title{
Short-term processing of ice algal- and phytoplankton- derived carbon by Arctic benthic communities revealed through isotope labelling experiments
}

\author{
Anni Mäkelä ${ }^{1 * *}$, Ursula Witte ${ }^{1}$, Philippe Archambault ${ }^{2}$ \\ ${ }^{1}$ School of Biological Sciences, University of Aberdeen, Aberdeen AB24 3UU, UK \\ ${ }^{2}$ Département de biologie, Québec Océan, Université Laval, Québec, QC G1V 0A6, Canada
}

\begin{abstract}
Benthic ecosystems play a significant role in the carbon $(C)$ cycle through remineralization of organic matter reaching the seafloor. Ice algae and phytoplankton are major $\mathrm{C}$ sources for Arctic benthic consumers, but climate change-mediated loss of summer sea ice is predicted to change Arctic marine primary production by increasing phytoplankton and reducing ice algal contributions. To investigate the impact of changing algal $\mathrm{C}$ sources on benthic $\mathrm{C}$ processing, 2 isotope tracing experiments on ${ }^{13} \mathrm{C}$-labelled ice algae and phytoplankton were conducted in the North Water Polynya (NOW; $709 \mathrm{~m}$ depth) and Lancaster Sound (LS; $794 \mathrm{~m}$ ) in the Canadian Arctic, during which the fate of ice algal $\left(\mathrm{C}_{\mathrm{IA}}\right)$ and phytoplankton $\left(\mathrm{C}_{\mathrm{PP}}\right) \mathrm{C}$ added to sediment cores was traced over $4 \mathrm{~d}$. No difference in sediment community oxygen consumption (SCOC, indicative of total $\mathrm{C}$ turnover) between the background measurements and ice algal or phytoplankton cores was found at either site. Most of the processed algal $\mathrm{C}$ was respired, with significantly more $\mathrm{C}_{\mathrm{PP}}$ than $\mathrm{C}_{\mathrm{IA}}$ being released as dissolved inorganic $\mathrm{C}$ at both sites. Macroinfaunal uptake of algal $\mathrm{C}$ was minor, but bacterial assimilation accounted for 33-44\% of total algal C processing, with no differences in bacterial uptake of $\mathrm{C}_{\mathrm{PP}}$ and $\mathrm{C}_{\mathrm{IA}}$ found at either site. Overall, the total processing (i.e. assimilation and respiration) of $\mathrm{C}_{\mathrm{PP}}$ was 33 and $37 \%$ higher than processing of $\mathrm{C}_{\mathrm{IA}}$ in NOW and in LS, respectively, suggesting that the future changes in quality of organic matter sinking to the seafloor could impact the $\mathrm{C}$ residence time at the seafloor.
\end{abstract}

KEY WORDS: Arctic $\cdot$ Carbon cycling $\cdot$ Sediment $\cdot$ Respiration $\cdot{ }^{13} \mathrm{C} \cdot$ Bacteria $\cdot$ Benthic-pelagic coupling $\cdot$ Sea ice cover

\section{INTRODUCTION}

Benthic communities below the euphotic zone rely on the particulate organic carbon (POC) exported from surface waters as their main $C$ source, which closely links the euphotic zone primary production (PP) to deep sea ecosystem functioning (Ambrose \& Renaud 1995, Gooday 2002). In the Arctic Ocean, the bulk of the organic matter flux to the seafloor is made up of the 2 main groups of primary producers: ice algae living in association with sea ice, and phytoplankton living in the water column. Ice algae can contribute up to $40 \%$ to overall annual PP in season-

${ }^{*}$ Corresponding author: anni.makela10@gmail.com ally ice-covered regions (Gosselin et al. 1997, Hegseth 1998, Forest et al. 2011, Dupont 2012), with their contribution increasing to $90 \%$ in the central Arctic Ocean (Matrai \& Apollonio 2013, FernándezMéndez et al. 2015). Ice algae can take advantage of low light levels and bloom early in the spring when zooplankton grazing is low (Hunt et al. 2002, Caron et al. 2004, Tremblay et al. 2006). This allows for a large proportion of the ice algal biomass to sink to the seafloor after ice break-up, where it provides an important initial C source for benthos after the foodlimited winter (McMahon et al. 2006, Boetius et al. 2013, North et al. 2014). However, climate change is

() The authors 2018. Open Access under Creative Commons by Attribution Licence. Use, distribution and reproduction are unrestricted. Authors and original publication must be credited. 
rapidly reducing the thickness and extent of the multi-year sea ice while delaying the formation of new first-year ice (Frey et al. 2015, Wang \& Overland 2015, Wood et al. 2015), changing the patterns of Arctic PP. As ice algae are dependent on sea ice for growth (Leu et al. 2015), the shortening of the icecovered period is likely to reduce ice algal PP (Søreide et al. 2010, Leu et al. 2011) and consequently, export of ice algal biomass to the seafloor (Carroll \& Carroll 2003). On the other hand, the longer open water period benefits pelagic algae as it increases their habitat and lengthens the phytoplankton growth season (Arrigo et al. 2008, Arrigo \& van Dijken 2015). As a consequence, the overall annual Arctic marine PP has increased by 1.6-10\% $\mathrm{yr}^{-1}$ since 1998 (Arrigo et al. 2008, Bélanger et al. 2013, Arrigo \& van Dijken 2015). The increasing phytoplankton PP has been proposed to enhance the efficiency of the biological pump that transports POC to the seafloor (Caron et al. 2004, Nishino et al. 2009, Manizza et al. 2013), although warmer conditions can also increase zooplankton grazing, limiting the C export (Piepenburg 2005, Carmack \& Wassmann 2006, Grebmeier et al. 2006b).

Benthic communities play a significant role in marine $\mathrm{C}$ cycling through assimilation and remineralization of the POC deposited at the seafloor (Moodley et al. 2005). The speed and magnitude of the processing depends on environmental factors such as water temperature (Moodley et al. 2005, Woulds et al. 2009), as well as the quantity (Bühring et al. 2006b, Morata et al. 2015) and quality (Byrén et al. 2006, Morata \& Renaud 2008, Mayor et al. 2012a, Hunter et al. 2013) of the organic matter available. High-quality organic matter is often characterized by having a high labile organic carbon content, often measured through the fatty acid composition and pigment and C:N ratios (Morata \& Renaud 2008, Mayor et al. 2012a, Hunter et al. 2013). Ice algae have a higher essential fatty acid content than phytoplankton (Falk-Petersen et al. 1998, McMahon et al. 2006, Sun et al. 2009, Wang et al. 2014), which makes them a superior-quality food item for marine consumers that require these fatty acids for growth and reproduction (Jónasdóttir et al. 2009, Søreide et al. 2010, Leu et al. 2011). Although ice algal aggregates can remain buoyant under sea ice due to photosynthetic gas bubble production (Assmy et al. 2013, Fernández-Méndez et al. 2014), ice algae rapidly sink below the euphotic zone once the buoyancy is lost, often reaching the deep seafloor within a day after being released to the water column (Syvertsen 1991, Haecky et al. 1998, Katlein et al. 2015). Phytoplankton, on the other hand, have a longer residence time in the water column due to the slow sinking rates and resuspension (Rutgers van der Loeff et al. 2002), which can lead to higher bacterial degradation during sinking, decreasing the quality of the algal cells reaching the seafloor (Morata \& Renaud 2008, Roy et al. 2015). As C respiration and uptake by benthos often increase with the quality of organic matter available (Morata \& Renaud 2008, Mayor et al. 2012a, Hunter et al. 2013), the decrease in high-quality ice algal inputs in favour of phytoplankton can impact sediment $\mathrm{C}$ cycling.

To date, only a few studies have investigated the responses of benthos to ice algae and phytoplankton, and the consequent impacts on C cycling processes. While certain bivalves and deposit feeding taxa preferentially consume ice algae over phytoplankton in shallow subtidal sites in Alaska and Svalbard (McMahon et al. 2006, Sun et al. 2009), other faunal communities efficiently assimilate both ice algal and phytoplankton $\mathrm{C}$, with no taxa in the Canadian Arctic deep sea exclusively preferring ice algae (Mäkelä et al. 2017a). Macrofaunal uptake, however, is usually a minor pathway in the total POC processing at the seafloor (Heip et al. 2001, Hunter et al. 2012, Findlay et al. 2015).

The responses of bacteria, which are major contributors to the processing of deposited phytodetritus (Gooday 2002, Moodley et al. 2002) are less understood. Sun et al. (2009) demonstrated rapid assimilation of ice algal $\mathrm{C}$ by sediment bacterial communities in Alaska, while both ice algal and phytoplankton inputs have been shown to stimulate bacterial growth during sediment incubation experiments (Sun et al. 2007, Hoffmann et al. 2017). The bacterial growth efficiency, describing the ratio of production of new biomass (bacterial secondary production) to remineralization of the organic C (bacterial respiration) (del Giorgio \& Cole 1998), is known to vary depending on the quality of the available $\mathrm{C}$ source (Tamburini et al. 2003, Mayor et al. 2012a), but the impacts of ice algae and phytoplankton on bacterial growth efficiency have been reported to be similar (Hoffmann et al. 2017).

Respiration, which refers to the oxidation of organic matter (here, POC) to yield energy, and to release $\mathrm{CO}_{2}$ (abiotic dissolved inorganic carbon, DIC) as a waste product (Findlay et al. 2015), is often the main pathway for POC processing in Arctic shelf sediments (Graf et al. 1995, Macdonald et al. 1998, Findlay et al. 2015). A commonly used proxy for assessing the benthic $\mathrm{C}$ respiration rates is measuring the sediment community oxygen consumption (SCOC), which can be converted into respiration rates using a $\mathrm{C}$ conver- 
sion factor (Rowe et al. 1997). Several studies have demonstrated that deposition of phytodetritus to the seafloor, often after spring algal blooms, triggers a measurable increase in SCOC rates (Rysgaard et al. 1998, Renaud et al. 2007b, 2008). Additionally, incubation experiments with added phytodetritus have shown SCOC to be higher after ice algal than phytoplankton deposition (McMahon et al. 2006, Sun et al. 2007), suggesting preferential respiration of ice algal POC by Arctic benthic communities. However, while SCOC provides an indication of the total $\mathrm{C}$ turnover, it encompasses both the biological respiration of all organisms in the sediments and the chemical oxidation of reduced compounds, without differentiating the role of different organisms in the measurement (Piepenburg 2005). As information on the role of specific benthic community fractions in the cycling of $\mathrm{C}$ in the Arctic Ocean is still limited (Piepenburg 2005, Werner et al. 2016), an isotope tracing approach can be applied to investigate the contributions of specific actors and pathways to POC processing (Witte et al. 2003b, Moodley et al. 2005, Gontikaki et al. 2011a). Addition of a ${ }^{13} \mathrm{C}$-enriched $\mathrm{C}$ source allows for the flow of the added $\mathrm{C}$ to be traced into tissues of consumers or through respiration via release of ${ }^{13} \mathrm{C}$-enriched DIC (to be distinguished from total C respiration calculated from SCOC), allowing for the rates of processing of the added $\mathrm{C}$ to be quantified (Peterson 1999). Additionally, the role of microbes in C processing can be shown through incorporation of the isotope tracer into bacterial specific biomarkers, such as certain phospholipid fatty acids (Boschker et al. 1998, Boschker \& Middelburg 2002). Following the fate of ice algal $\left(\mathrm{C}_{\mathrm{IA}}\right)$ and phytoplankton $\left(\mathrm{C}_{\mathrm{PP}}\right) \mathrm{C}$ through different $\mathrm{C}$ processing pathways therefore allows us to estimate the potential impact of changing the $C$ source on benthic ecosystem functioning.

The aim of this study was to compare, through isotope labelling experiments, the short-term processing of $\mathrm{C}_{\mathrm{IA}}$ and $\mathrm{C}_{\mathrm{PP}}$ by intact Arctic deep sea benthic communities in 2 Canadian Arctic Archipelago sites, i.e. the North Water Polynya and Lancaster Sound. Detailed macroinfaunal uptake of $\mathrm{C}_{\mathrm{IA}}$ and $\mathrm{C}_{\mathrm{PP}}$ during the experiments is reported in Mäkelä et al. (2017a). Here the fate of $\mathrm{C}_{\mathrm{IA}}$ and $\mathrm{C}_{\mathrm{PP}}$ is traced through algal-derived respiration (i.e. release of $\mathrm{DI}^{13} \mathrm{C}$ ) and assimilation into bacterial biomass during $4 \mathrm{~d}$ incubation experiments. Additionally, the impact of ice algae and phytoplankton on bacterial growth efficiency and the total sediment C turnover, calculated from SCOC, were measured. We hypothesize that the rates of $\mathrm{C}_{\mathrm{IA}}$ processing (release of $\mathrm{DI}^{13} \mathrm{C}$ and bacterial uptake) are higher than $\mathrm{C}_{\mathrm{PP}}$ processing rates at both sites.

\section{MATERIALS AND METHODS}

\section{Sampling sites}

The experiments took place aboard the research icebreaker CCGS 'Amundsen' during the ArcticNet 2013 cruise. The 2 study locations, the North Water Polynya (NOW, Station 124) and Lancaster Sound (LS, Station 323), are located in western Baffin Bay in the Canadian Arctic Archipelago (Fig. 1, Table 1). The sites are known as hotspots for both Arctic marine PP (Klein et al. 2002, Lalande et al. 2009, Roy et al. 2015) and benthic faunal diversity and biomass (Thomson 1982, Link et al. 2013b, Mäkelä et al. $2017 \mathrm{~b})$. The annual PP rates in LS (60 $\mathrm{g} \mathrm{C} \mathrm{m}^{-2} \mathrm{yr}^{-1}$ ) and NOW (254 $\mathrm{g} \mathrm{C} \mathrm{m}^{-2} \mathrm{yr}^{-1}$ ) (Welch et al. 1992, Klein et al. 2002) are dominated by phytoplankton, with 3 and $10 \%$ of PP attributed to ice algae in NOW and LS, respectively (Welch et al. 1992, Michel et al. 2002, Tremblay et al. 2006). The difference in the type and magnitude of PP creates an interesting contrast between LS and NOW, which contributed to the study site selection. Sampling sites are described in detail in Mäkelä et al. (2017a,b).

\section{Algal cultures}

Prior to the experiments, axenic cultures of the pennate ice algal species Synedropsis hyperborea (CCMP 1422) and the centric phytoplankton species Thalassiosira nordenskioeldii (CCMP 995, both Bigelow Laboratory for Ocean Sciences) were grown in the laboratory at $0^{\circ} \mathrm{C}$ on a $12: 12 \mathrm{~h}$ light:dark cycle in f/2 artificial seawater media (Grasshoff et al. 1999), amended with $50 \%{ }^{13} \mathrm{C}$-bicarbonate and $50 \%{ }^{15} \mathrm{~N}$ nitrate. The seawater was sterilized prior to the addition of filter-sterilized nutrients. Both species are diatoms and are commonly found in the ice algal and phytoplankton communities, respectively, in the Arctic Ocean (Hegseth 1998, Lovejoy et al. 2002, von Quillfeldt et al. 2003, Tamelander et al. 2009). The algae were harvested by centrifugation, freeze dried and stored at $-80^{\circ} \mathrm{C}$ until the research cruise.

\section{Sample collection and experimental design}

Sample collection and experimental design are described in detail in Mäkelä et al. (2017a). Briefly, 2 USNEL box cores $\left(0.25 \mathrm{~m}^{2}\right)$ were taken from the seafloor at each station to allow for the collection of 15 sediment cores $(\sim 40 \mathrm{~cm}$ tall, $9.4-10 \mathrm{~cm}$ diam- 


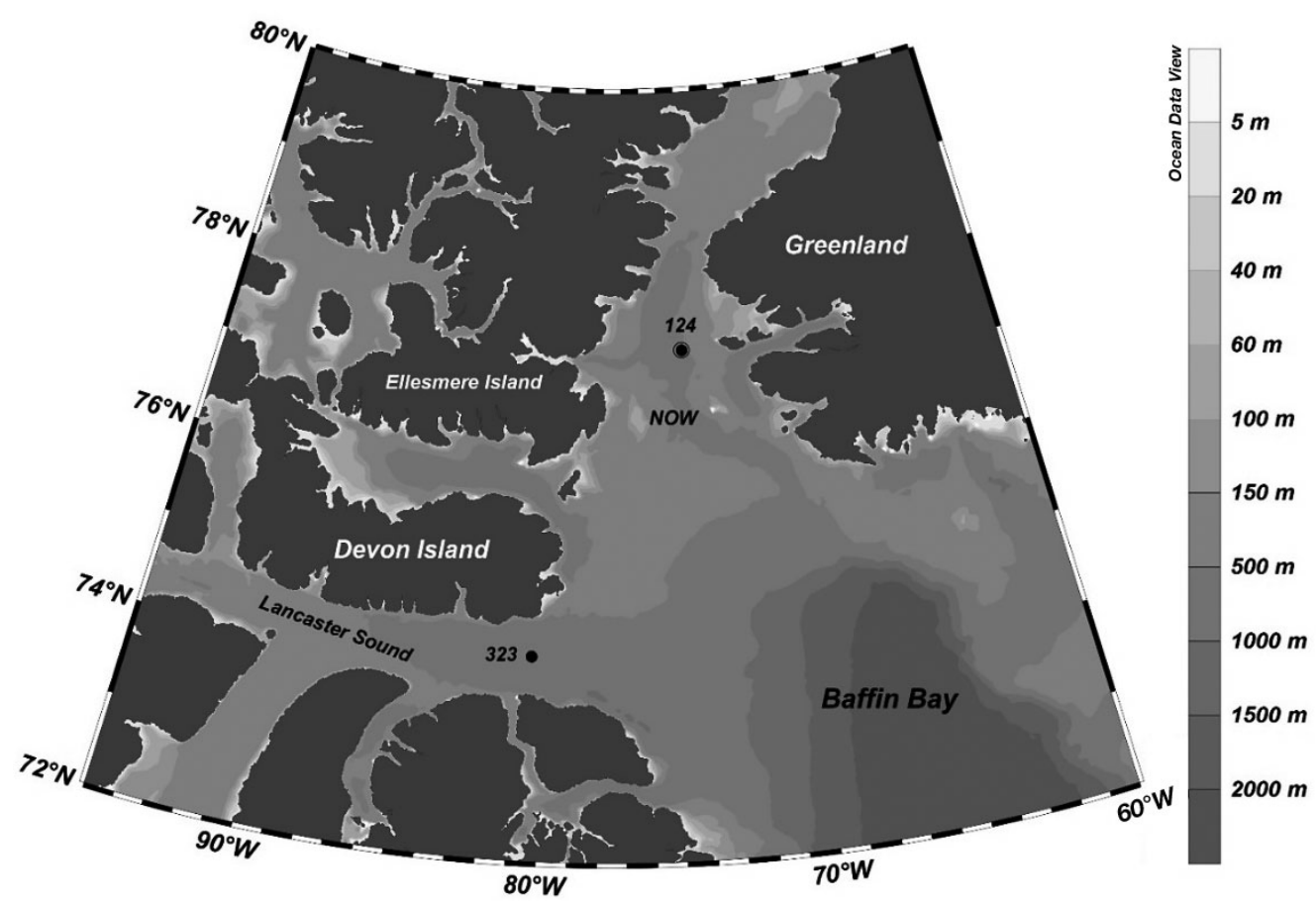

Fig. 1. Locations of the sampling sites in the North Water Polynya (NOW, Stn 124) and Lancaster Sound (LS, Stn 323) in the Canadian Arctic Archipelago

Table 1. Station locations and hydrographic and sediment characteristics during the ArcticNet 2013 cruise

\begin{tabular}{|lcc|}
\hline Parameter & $\begin{array}{c}\text { Lancaster } \\
\text { Sound }\end{array}$ & $\begin{array}{c}\text { North Water } \\
\text { Polynya }\end{array}$ \\
\hline ArcticNet 2013 station number & 323 & 124 \\
Date sampled & 14 August 2013 & 27 August 2013 \\
Depth $(\mathrm{m})$ & 794 & 709 \\
Latitude & $74^{\circ} 9.41 \mathrm{~N}$ & $77^{\circ} 20.79 \mathrm{~N}$ \\
Longitude & $80^{\circ} 28.32 \mathrm{~W}$ & $74^{\circ} 17.50 \mathrm{~W}$ \\
Bottom $\mathrm{O}_{2}$ concentration $\left(\mathrm{ml} \mathrm{l}^{-1}\right)$ & 4.1 & 5.6 \\
Bottom temperature $\left({ }^{\circ} \mathrm{C}\right)$ & 1.2 & -0.1 \\
Bottom salinity & 34.5 & 34.4 \\
Ice free conditions before sampling $(\mathrm{d})$ & 59 & 79 \\
\hline
\end{tabular}

acted as controls (without algal addition) for background SCOC measurements and bacterial phospholipid fatty acid and macrofaunal $\delta^{13} \mathrm{C}$ signatures, while 6 experimental cores were amended with ice algae and 6 cores with phytoplankton. The cores were incubated for $4 \mathrm{~d}$ in darkness at $4^{\circ} \mathrm{C}$. The overlying water column was continuously stirred with magnetic stirrers attached to a motor on the core lid. Oxygen concentration was recorded once a day using an oxygen dipping probe (DP-PSt3 and Fibox 3

eter). The sub-cores were topped with bottom water, sealed and allowed to settle for 8-15 h before algae were added to the cores to mark the beginning of the experiments. The amount of algae added corresponded to $25 \%$ of the estimated annual POC flux at the study sites, but as no POC flux data for LS exist, the POC export estimate for Cape Bathurst Polynya (Lalande et al. 2009) was used as a reference point following the approach of Mäkelä et al. (2017a). The resulting algal additions were $1475 \mathrm{mg} \mathrm{C} \mathrm{m}^{-2}$ in NOW and $600 \mathrm{mg} \mathrm{C}$ $\mathrm{m}^{-2}$ in LS, adjusted to $\mathrm{C}$ content of ice algae and phytoplankton appropriately. At each site, 3 cores
LCD-trace v6, PreSens), inserted through a small opening in the core lid. A $10 \mathrm{ml}$ water sample was taken every day for DIC analysis, and the water volume was replaced by previously collected bottom water from the sampling sites. The DIC samples were filtered through a $0.2 \mu \mathrm{m}$ syringe filter into a gas-tight $3.6 \mathrm{ml}$ glass vial poisoned with saturated $\mathrm{HgCl}_{2}$ to stop bacterial activity, and stored at $4^{\circ} \mathrm{C}$ until analysis. At the end of the experiments, the cores were halved vertically, with one half used for macrofaunal tissue isotope analysis. For detailed macrofaunal sample preparation, analysis and algal uptake results see Mäkelä et al. 
$(2017 \mathrm{a}, \mathrm{b})$. The other half was sliced at $0-0.5,0.5-1$ and $1-2 \mathrm{~cm}$ sediment horizons and stored at $-80^{\circ} \mathrm{C}$ for phospholipid fatty acid analysis to examine bacterial biomass and label uptake. Three control, ice algal and phytoplankton cores each were analysed for phospholipid fatty acids. The sediments were freeze dried prior to lipid extractions.

\section{Respiration of labelled algae}

In the laboratory, $100 \mu \mathrm{l}$ of each poisoned water sample were pipetted into a $12 \mathrm{ml}$ Exetainer ${ }^{\circledR}$ vial and capped. The vials were then flush-filled with $\mathrm{N}_{2}$ gas using a Gas-bench II (Thermo Finnigan), and $100 \mu \mathrm{l}$ of $1.3 \mathrm{M} \mathrm{H}_{3} \mathrm{PO}_{4}$ were injected through the septa of the cap into the sample and left overnight. The $\mathrm{C}$ isotope ratio of the $\mathrm{CO}_{2}$ released into the headspace of the Exetainers was analysed using a Gas-bench II connected to a DeltaPlus Advantage isotope ratio mass spectrometer (Thermo Finnigan). Through use of the Valco valve and a sample loop within the gas bench and the instrument Isodat NT software version 2.0, each Exetainer was sampled 9 times, of which the last 5 values were averaged to give a single sample value. The carbon isotope ratios, all expressed relative to Vienna PeeDee belemnite (VPDB), were traceable to International Atomic Energy Agency (IAEA) reference material NBS 19 TS-Limestone. Repeated analysis of a quality control standard gas indicated that the precision of the gas bench for analysing $\delta^{13} \mathrm{C}$ of $\mathrm{CO}_{2}$ at a concentration of $450 \mathrm{ppm}$ in exetainers was $-35.03 \pm 0.24 \%$ (mean $\pm \mathrm{SD}, \mathrm{n}=65$ ).

\section{Lipid extraction and separation}

The lipids were extracted following the extraction protocol of Bligh \& Dyer (1959) as modified by White et al. (1979). Approximately $3 \mathrm{~g}$ of freeze-dried sediment were weighed into glass centrifuge tubes and extracted with a single-phase extraction mixture containing chloroform, methanol and citrate buffer (1:2:0.8 v:v:v) over $2 \mathrm{~h}$. The total lipid extract was fractionated on silicic acid columns (6 ml ISOLUTE SI SPE columns, International Sorbent Technologies) by sequential elution with chloroform (neutral lipids), acetone (glycolipids) and methanol (phospholipids). Phospholipids were transmethylated under alkaline methanolysis to obtain fatty acid methyl esters (FAMEs).

\section{FAME quantification and identification and com- pound-specific $\delta^{13} \mathrm{C}$ determination}

The quantity and $\delta^{13} \mathrm{C}$ signature of individual FAMEs was determined simultaneously on a GC Trace Ultra with combustion column attached via a GC Combustion III to a Delta V Advantage isotope ratio mass spectrometer (all Thermo Finnigan). Running conditions, data processing and peak identification are described by Main et al. (2015). The $\delta^{13} \mathrm{C}_{\mathrm{VPDB}}$ values $(\%)$ of the FAMEs were calculated with respect to a $\mathrm{CO}_{2}$ reference gas injected with every sample and traceable to IAEA reference material NBS 19 TS-Limestone. Typical $\delta^{13} \mathrm{C}$ FAME analysis precision for natural abundance samples was confirmed by the $\delta^{13} \mathrm{C}$ values determined for the $\mathrm{C} 19$ internal standard added to all samples, with $\delta^{13} \mathrm{C}=$ $-32.44 \pm 0.67 \%$ o (mean $\pm \mathrm{SD}, \mathrm{n}=23$ ), as reported by Main et al. (2015). Measurement of the Indiana University reference material hexadecanoic acid methyl ester no. 1 (certified $\delta^{13} \mathrm{C}_{\mathrm{VPDB}}=-30.74 \pm 0.01 \%$ ) gave a value of $-30.86 \pm 0.17 \%$ o $(n=13)$. Due to high enrichment of our samples, some carryover from sample enrichment into C19 internal standard was found, with the average $\delta^{13} \mathrm{C}=-37.70 \pm 4.64 \%$ o $(\mathrm{n}=$ $41)$, but the effect of this in comparison to overall enrichment is minimal. The combined area of mass peaks $(\mathrm{m} / \mathrm{z} 44,45$ and 46$)$ after background subtraction were collected for each individual FAME peak. These combined areas, relative to those of the internal standard, were used to quantify 43 FAMEs and subsequently the phospholipid fatty acids (PLFAs) from which they were derived as described by Thornton et al. (2011).

\section{Label uptake calculations}

Stable isotope values are expressed in the $\delta$ notion (\%) relative to the reference material according to the equation:

$$
\left.\delta^{13} \mathrm{C}(\%)=R_{\text {sample }}-R_{\text {reference }}\right)-1 \times 1000
$$

where $R_{\text {sample }}$ is the ${ }^{13} \mathrm{C}:{ }^{12} \mathrm{C}$ ratio of the sample and $R_{\text {reference }}$ is the ${ }^{13} \mathrm{C}:{ }^{12} \mathrm{C}$ ratio of the VPDB reference material $\left(R_{\mathrm{VPDB}}=0.0112372\right)$. The incorporation of ${ }^{13} \mathrm{C}$ $\left(I_{\text {DIC }}\right.$ or $\left.I_{\text {PLFA }}\right)$ was calculated from the excess ${ }^{13} \mathrm{C}(E)$ and the concentration of DIC or bacteria-specific PLFAs using the formula:

$$
\begin{gathered}
I=E \times \text { PLFA or DIC concentration } \\
\left(\text { in } \mu g^{-1} \text { or } \mu \mathrm{mol} \mathrm{ml} \mathrm{gl}^{-1}\right)
\end{gathered}
$$


Excess ${ }^{13} \mathrm{C}(E)$ is calculated as:

$$
E=F_{\text {sample }}-F_{\text {background }}
$$

where $F=R /(R+1)$ and $R=\left(\delta^{13} \mathrm{C} / 1000+1\right) \times R_{\mathrm{VPDB}}$. The background DIC $\delta^{13} \mathrm{C}$ was obtained from Day 0 measurement of each experimental core to account for any introduction of ${ }^{13} \mathrm{C}$-bicarbonate when adding the labelled algae (Moodley et al. 2005). The bacterial PLFA background $\delta^{13} \mathrm{C}$ was calculated from the average of the 3 control cores at each site and time point. The incorporation of algal label by bacteria was based on the ${ }^{13} \mathrm{C}$ labelling of the most common bacteria specific PLFAs in the sediment (i14:0, i15:0, a15:0 and i16:0) (Moodley et al. 2002, 2005, Evrard et al. 2010). The total incorporation into bacterial biomass was calculated following Middelburg et al. (2000):

$$
I_{\text {bacteria }}=\sum\left[I_{\mathrm{PLFA}} /(a \times b)\right]
$$

where $I_{\text {bacteria }}=$ incorporation into bacterial biomass, $a=$ average PLFA concentration in bacteria $(0.056 \mathrm{~g}$ PLFA C $\mathrm{g}^{-1}$ of $\mathrm{C}$ biomass) (Brinch-Iversen \& King 1990), and $b=$ fraction of the bacteria-specific PLFAs found in the sediment samples at each station $(\mathrm{NOW}=0.085, \mathrm{LS}=0.087)$. Finally, the total algal $\mathrm{C}$ incorporation into bacterial biomass and DIC pool $\left(I_{\text {algae }}\right)$ was then calculated as a quotient of the algal labelling factor for ice algae and phytoplankton (ice algae: 60.1 atom $\%{ }^{13} \mathrm{C}$ and phytoplankton 53.8 atom $\%{ }^{13} \mathrm{C}$ ) following the equation:

$$
I_{\text {algae }}=\left(I_{\text {bacteria }} \text { or } I_{\text {DIC }}\right) / \text { labelling factor }
$$

Bacterial biomass was calculated from the concentration of the bacteria-specific PLFAs at each site and the average PLFA concentration in bacteria (0.056).

Bacterial growth efficiencies were estimated following Mayor et al. (2012a), where the partitioning of respiration between macrofaunal and bacterial components was calculated using the equation:

$$
R_{\mathrm{B}}=R_{\mathrm{T}}-\left[I_{\mathrm{M}} / \mathrm{NPE}_{\mathrm{M}} \times\left(1-\mathrm{NPE}_{\mathrm{M}}\right)\right]
$$

where $R_{\mathrm{B}}$ and $R_{\mathrm{T}}$ are the bacterial and total respiration of algal-derived $\mathrm{C}$, respectively, $I_{\mathrm{M}}$ is the total macrofaunal algal-derived C uptake from Mäkelä et al. (2017a), and $\mathrm{NPE}_{\mathrm{M}}$ is the net production efficiency of macrofauna, which was assumed to be 0.5. Bacterial growth efficiency (BGE) was then estimated using the equation:

$$
\mathrm{BGE}=\frac{I_{B}}{\left(I_{B}+R_{B}\right)}
$$

where $I_{\mathrm{B}}$ is the total algal-derived $\mathrm{C}$ assimilation into bacterial biomass.

\section{Statistical analysis}

The oxygen flux, or SCOC, was calculated from the slope of the linear regression of oxygen concentration over time during the $4 \mathrm{~d}$ incubation. The SCOC was converted to benthic $\mathrm{C}$ respiration assuming a respiration quotient of 0.85 (Rowe 1983).

Differences in the macrofaunal biomasses between the control $(n=3)$, ice algae $(n=6)$ and phytoplankton $(n=6)$ cores within stations were tested using a Kruskal-Wallis test (as the normality assumption of at least one of the groups was not met), and differences in bacterial biomasses using a 1-way ANOVA, followed by a Bonferroni post hoc test when significant differences were found. Differences in the SCOC between the control cores $(n=3)$ at NOW and LS were tested using an independent samples $t$-test, and within-site differences between the control and experimental cores (6 ice algae and 6 phytoplankton) were examined using a 1-way ANOVA followed by a Bonferroni test when appropriate. The treatment effect was tested separately for the 2 study sites, as the absolute amounts of algae added to the experimental cores were different. Differences in the bacterial assimilation of $\mathrm{C}_{\mathrm{IA}}$ and $\mathrm{C}_{\mathrm{PP}}(\mathrm{n}=3$ each), and slopes of ice algae $(n=6)$ and phytoplankton $(n=6)$ derived DIC release over time within the sites were tested with an independent samples $t$-test. The normality of the data residuals was tested using the Shapiro-Wilk test, and the homogeneity of residual variance was tested visually. Deviations from homogeneity of variance assumption were corrected by using the Welch correction when appropriate. All values are presented $\pm \mathrm{SE}$ of the mean.

\section{RESULTS}

\section{Bacterial and macroinfaunal biomass}

While in the control cores macroinfaunal biomass was higher than bacterial biomass at both sites, the opposite was found in the ice algae and phytoplankton cores after rapid increase of bacterial biomass following algal addition (Table 2). No statistically significant differences in the macroinfaunal biomass between the 3 control and the 6 ice algal and 6 phytoplankton treatment cores in NOW were observed $\left(\chi^{2}=5.025, \mathrm{df}=2, \mathrm{p}=0.081\right)$ or $\mathrm{LS}\left(\chi^{2}=3.525, \mathrm{df}=2\right.$ ， $\mathrm{p}=0.172)$. A 1-way ANOVA showed significant differences in bacterial biomass between control, ice algal and phytoplankton cores in NOW $\left(F_{2,7}=9.102\right.$, $\mathrm{p}=0.011$ ), and a Bonferroni post hoc test showed that 
Table 2. Bacterial and macroinfaunal biomass $\left(\mathrm{g} \mathrm{C} \mathrm{m}^{-2}\right)$ in control, ice algal and phytoplankton cores in the North Water Polynya (NOW) and Lancaster Sound (LS). Values are means \pm SE. Bacterial biomass is estimated from the concentration of bacterial specific fatty acids (iC14:0, iC15:0, aiC15:0, iC16:0)

\begin{tabular}{|c|c|c|c|c|c|c|}
\hline \multirow{2}{*}{$\begin{array}{l}\text { Sediment layer } \\
(\mathrm{cm})\end{array}$} & \multicolumn{3}{|c|}{ - NOW - } & \multirow[b]{2}{*}{ Control } & \multirow{2}{*}{$\begin{array}{l}\text { LS } \\
\text { Ice algae }\end{array}$} & \multirow[b]{2}{*}{ Phytoplanktor } \\
\hline & Control & Ice algae & Phytoplankton & & & \\
\hline \multicolumn{7}{|c|}{ Bacterial biomass (g C m m $^{-2}$ ) } \\
\hline $0-0.5$ & $1.16 \pm 0.22$ & $1.42 \pm 0.12$ & $1.26 \pm 0.19$ & $0.72 \pm 0.27$ & $0.96 \pm 0.19$ & $1.39 \pm 0.10$ \\
\hline $0.5-1$ & $0.44 \pm 0.08$ & $1.04 \pm 0.06$ & $1.36 \pm 0.36$ & $0.34 \pm 0.31$ & $0.73 \pm 0.02$ & $0.69 \pm 0.11$ \\
\hline $1-2$ & $0.82 \pm 0.11$ & $1.57 \pm 0.08$ & $1.31 \pm 0.08$ & $0.50 \pm 0.02$ & $0.92 \pm 0.17$ & $1.10 \pm 0.02$ \\
\hline Total 0-2 & $2.42 \pm 0.32$ & $4.04 \pm 0.20$ & $3.94 \pm 0.39$ & $1.56 \pm 0.57$ & $2.60 \pm 0.36$ & $3.18 \pm 0.20$ \\
\hline \multicolumn{7}{|c|}{ Macroinfaunal biomass (g C m${ }^{-2}$ ) } \\
\hline $0-10$ & $3.77 \pm 0.25$ & $2.58 \pm 0.34$ & $2.77 \pm 0.25$ & $2.12 \pm 0.96$ & $2.73 \pm 0.69$ & $1.53 \pm 0.18$ \\
\hline
\end{tabular}

the control core biomass was lower than the biomass in ice algae $(p=0.016)$ and phytoplankton $(p=0.031)$ cores. No significant differences between ice algae and phytoplankton cores were found $(p=1.000)$ in NOW. No statistically significant differences in bacterial biomass between the ice algal, phytoplankton and control cores were found in $\operatorname{LS}\left(F_{2,5}=4.645, \mathrm{p}=\right.$ 0.072).

\section{$\mathrm{SCOC}$}

No significant difference in the background SCOC (measured from the 3 control cores) between the 2 stations was found ( $t=0.948, \mathrm{df}=4, \mathrm{p}=0.397$; Fig. 2). A 1-way ANOVA revealed significant differences in the SCOC between the control, ice algal and phytoplankton treatment cores in LS $\left(F_{2,12}=4.280, \mathrm{p}=\right.$ 0.040), and a Bonferroni test showed that SCOC in phytoplankton cores was significantly higher than in ice algal cores $(p=0.038)$. No significant differences between the control, ice algal and phytoplankton core SCOC were found in NOW $\left(F_{2,12}=1.231, \mathrm{p}=0.326\right)$.

\section{Respiration of $\mathrm{C}_{\mathrm{IA}}$ and $\mathrm{C}_{\mathrm{PP}}$}

At the end of Day 4, 111 and $134 \mathrm{mg}$ $\mathrm{C} \mathrm{m}^{-2}$ of $\mathrm{C}_{\mathrm{IA}}$ and $\mathrm{C}_{\mathrm{PP}}$ were respired in NOW, compared to 31 and $43 \mathrm{mg} \mathrm{C}$ $\mathrm{m}^{-2}$ in LS (Fig. 3). Respiration of $\mathrm{C}_{\mathrm{PP}}$ was significantly higher than $\mathrm{C}_{\mathrm{IA}}$ both in NOW ( $t=-2.657, \mathrm{df}=8, \mathrm{p}=0.029$ ) and in LS $(t=-4.799, \mathrm{df}=7.274, \mathrm{p}=$ 0.002). In LS, $51 \%$ (ice algae) and $30 \%$ (phytoplankton) and in NOW 60\%

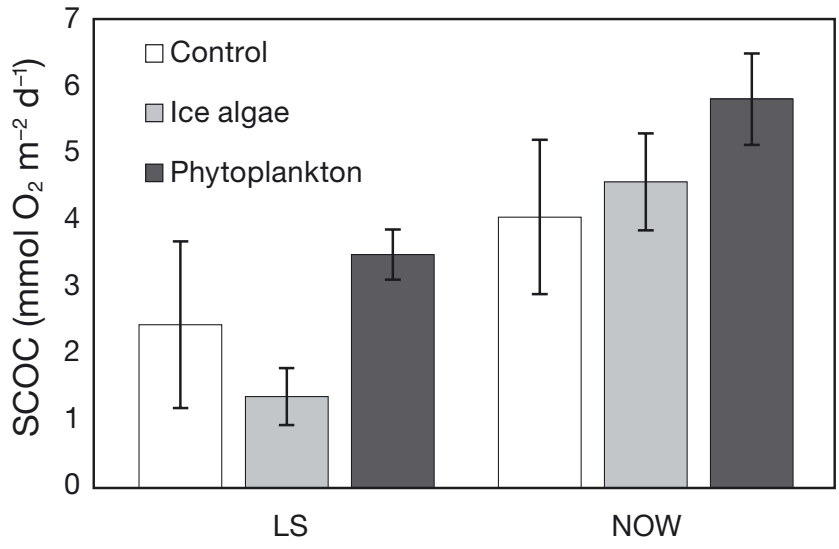

Fig. 2. Mean $( \pm \mathrm{SE})$ sediment community oxygen consumption (SCOC) in the control $(\mathrm{n}=3)$ and ice algal and phytoplankton treatment cores ( $\mathrm{n}=6$ each) in the North Water Polynya (NOW) and Lancaster Sound (LS)

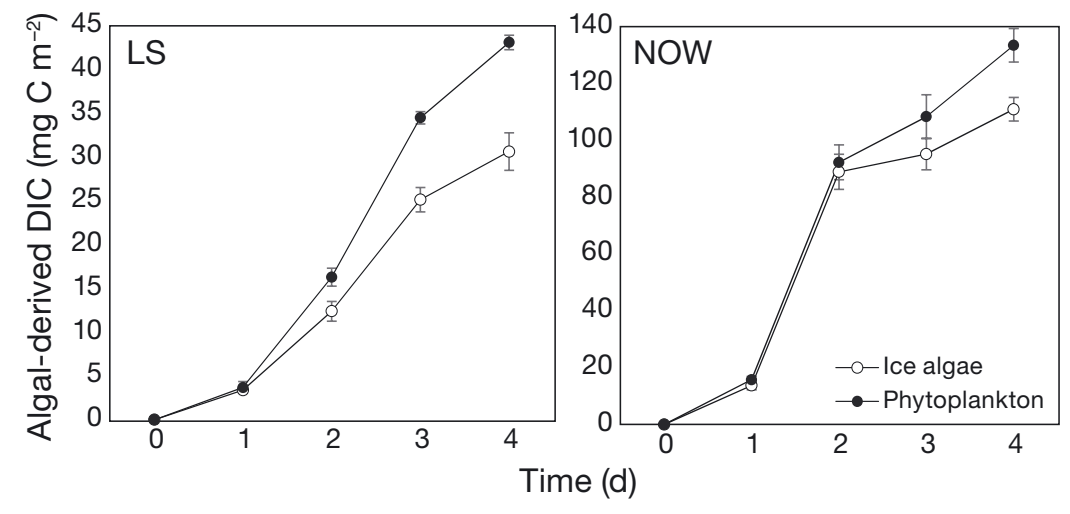

Fig. 3. Ice algal- and phytoplankton-derived $\mathrm{C}$ respiration (i.e. release of dissolved inorganic carbon, DIC) over the duration of the incubation experiments in North Water Polynya (NOW) and Lancaster Sound (LS). Data are mean \pm SE. Three cores were analysed for time points 1 and 3, and 5 (NOW) and 6 (LS) cores for time points 0,2 and 4. Note differences in $y$-axes scales 


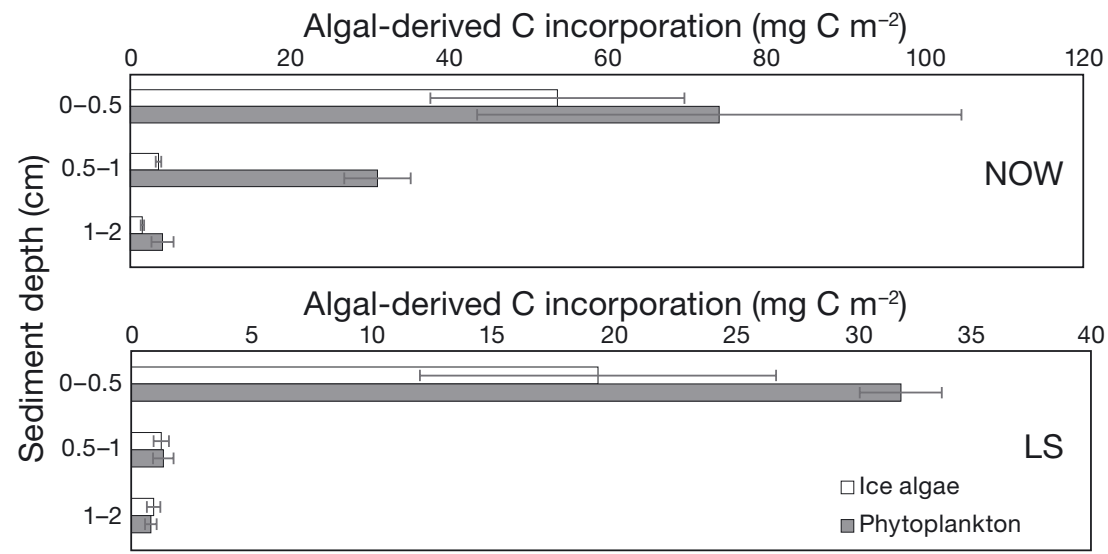

Fig. 4. Mean incorporation ( $\pm \mathrm{SE}, \mathrm{n}=3$ each) of ice algal- and phytoplanktonderived $\mathrm{C}$ into pooled bacterial fatty acids in the North Water Polynya (NOW) and Lancaster Sound (LS) during $4 \mathrm{~d}$ incubations. Note differences in $x$-axes scales

(both ice algae and phytoplankton) of total benthic respiration (derived from $\mathrm{SCOC}$ ) was attributed to respiration of added algal $\mathrm{C}$. Total bacterial respiration of $\mathrm{C}_{\mathrm{PP}}$ was significantly higher than respiration of $\mathrm{C}_{\mathrm{IA}}$ at both LS $\left(40.2 \pm 1.9\right.$ vs. $25.9 \pm 2.9 \mathrm{mg} \mathrm{C} \mathrm{m}^{-2}$, $t=-4.217, \mathrm{df}=4, \mathrm{p}=0.014)$ and NOW $(128.9 \pm 7.4 \mathrm{vs}$. $\left.105.2 \pm 3.8 \mathrm{mg} \mathrm{C} \mathrm{m}^{-2}, t=-3.113, \mathrm{df}=5, \mathrm{p}=0.026\right)$. However, the difference in biomass-specific respiration of $\mathrm{C}_{\mathrm{IA}}$ and $\mathrm{C}_{\mathrm{PP}}$ by bacterial communities in LS $\left(10.3 \pm 1.9 \mathrm{mg} \mathrm{C}_{\mathrm{IA}} \mathrm{g}^{-1}\right.$ and $\left.12.8 \pm 1.3 \mathrm{mg} \mathrm{C}_{\mathrm{PP}} \mathrm{g}^{-1}\right)$ was not statistically significant $(t=-1.097, \mathrm{df}=4, \mathrm{p}=$ 0.344 ), but in NOW, significantly more $\mathrm{C}_{\mathrm{PP}}$ (33.1. \pm $\left.1.7 \mathrm{mg} \mathrm{C} \mathrm{g}^{-1}\right)$ than $\mathrm{C}_{\text {IA }}\left(26.3 \pm 1.8 \mathrm{mg} \mathrm{C} \mathrm{g}^{-1}\right)$ was respired by the bacteria $(t=-2.624, \mathrm{df}=5, \mathrm{p}=0.047)$.

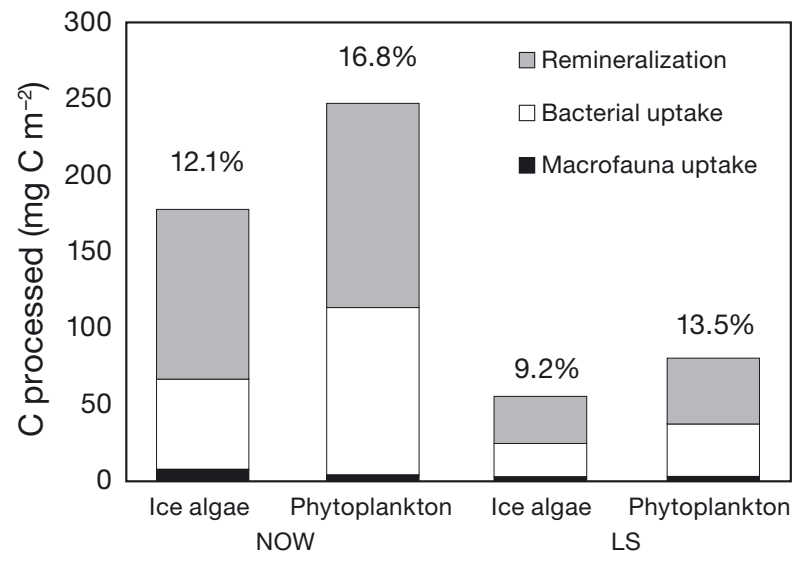

Fig. 5. Mean amount of ice algal- and phytoplankton-derived $\mathrm{C}$ taken up by bacteria and macrofauna and released as dissolved inorganic $\mathrm{C}$ in the North Water Polynya (NOW) and Lancaster Sound (LS). Data on macrofaunal uptake are from Mäkelä et al. (2017a). The value above the columns refers to the average \% of added algae processed by the benthic community by the end of the $4 \mathrm{~d}$ incubations

\section{Incorporation of $\mathrm{C}_{\mathrm{IA}}$ and $\mathrm{C}_{\mathrm{PP}}$ into bacterial biomass}

The total amounts of $\mathrm{C}_{\mathrm{PP}}$ and $\mathrm{C}_{\mathrm{IA}}$ incorporated into bacterial biomass in NOW were $109.6 \pm 28.9$ and $59.0 \pm$ $16.5 \mathrm{mg} \mathrm{C} \mathrm{m}^{-2}$, respectively, whereas in LS the corresponding amounts were $34.3 \pm 1.4$ and $21.7 \pm 8.0 \mathrm{mg} \mathrm{C} \mathrm{m}^{-2}$ (Fig. 4). No significant differences between the ice algae and phytoplankton treatments were found in NOW $(t=-1.519, \mathrm{df}=4, \mathrm{p}=0.203)$ or LS $(t=$ $-1.552, \mathrm{df}=2.117, \mathrm{p}=0.254)$. When normalized to biomass, the bacteria in NOW incorporated $44.3 \pm 12.2 \mathrm{mg}$ $\mathrm{C}_{\mathrm{IA}} \mathrm{g}^{-1}$ and $84.5 \pm 23.8 \mathrm{mg} \mathrm{C}_{\mathrm{PP}} \mathrm{g}^{-1}$, whereas in LS, the uptake was $21.6 \pm$ $5.2 \mathrm{mg} \mathrm{C}_{\mathrm{IA}} \mathrm{g}^{-1}$ and $26.1 \pm 1.7 \mathrm{mg} \mathrm{C}_{\mathrm{PP}} \mathrm{g}^{-1}$. These differences were not significant at NOW $(t=-1.501, \mathrm{df}=4$, $\mathrm{p}=0.208)$ or $\mathrm{LS}(t=-0.811, \mathrm{df}=4, \mathrm{p}=0.463)$. The bacterial growth efficiency, calculated from the amounts of added $\mathrm{C}$ assimilated vs. respired by the bacterial communities, were 0.36 (ice algae) and 0.46 (phytoplankton) in NOW, and 0.44 (ice algae) and 0.46 (phytoplankton) in LS.

\section{Total $\mathrm{C}_{\mathrm{IA}}$ and $\mathrm{C}_{\mathrm{PP}}$ processing}

After $4 \mathrm{~d}$ of incubation, the total amounts of $\mathrm{C}_{\mathrm{PP}}$ and $\mathrm{C}_{\mathrm{IA}}$ processed (including algal-derived respiration, assimilation into bacterial biomass and uptake by macrofauna) by the NOW benthic community were 247.2 and $177.9 \mathrm{mg} \mathrm{C} \mathrm{m}{ }^{-2}$, respectively, whereas in LS, 80.7 and $55.4 \mathrm{mg} \mathrm{C} \mathrm{m}^{-2}$ were processed (Fig. 5). The major pathways of $\mathrm{C}$ processing at both stations were bacterial respiration and assimilation, whereas the role of macroinfauna was small (Fig. 6).

\section{DISCUSSION}

\section{Benthic C respiration}

The responses of benthic communities to algal addition were investigated through changes in benthic $\mathrm{C}$ respiration rates. The $\mathrm{C}$ respiration rates were determined from 2 measurements: $\mathrm{SCOC}$, a common method used for assessing the total benthic $\mathrm{C}$ turnover, and release of $\mathrm{DI}^{13} \mathrm{C}$, a direct measurement of the respiration of the added $\mathrm{C}_{\mathrm{IA}}$ and $\mathrm{C}_{\mathrm{PP}}$. 

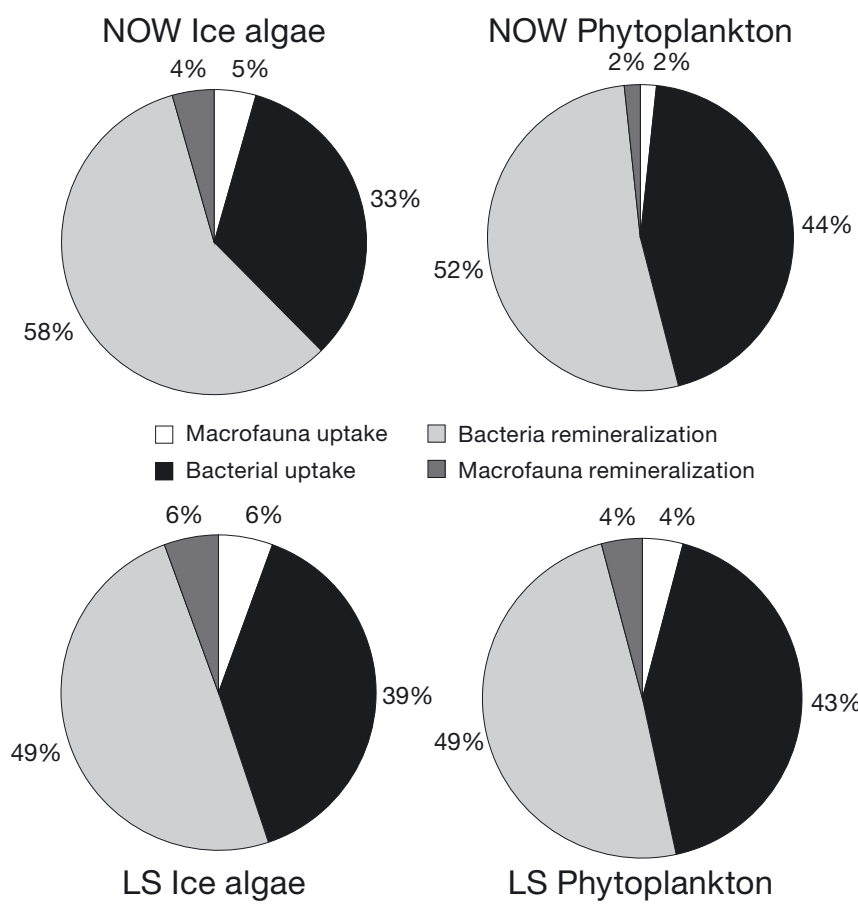

Fig. 6. Contribution of each measured pathway to the overall ice algal- and phytoplankton-derived $\mathrm{C}$ processing in the North Water Polynya (NOW) and Lancaster Sound (LS) after $4 \mathrm{~d}$ incubations. Data on macrofaunal uptake are from Mäkelä et al. (2017a)

We hypothesized that ice algae would be the preferred $\mathrm{C}$ source for the benthos, and therefore the rates of $\mathrm{C}_{\mathrm{IA}}$ respiration would be higher than rates of $\mathrm{C}_{\mathrm{PP}}$ respiration. As $\mathrm{SCOC}$ is an indiscriminate measurement of the respiration taking place in the sediment cores, only DIC release, which can be specifically associated with ice algae or phytoplankton, was used to investigate the hypothesis. SCOC was higher in phytoplankton than ice algal cores in LS, but neither measurement was significantly different from the control core measurements. Additionally, no difference between the treatments was found in NOW. The DIC release, however, revealed significant differences in respiration of algal-derived $\mathrm{C}$ by the benthos, with 18-34\% higher respiration of $\mathrm{C}_{\mathrm{PP}}$ than $\mathrm{C}_{\mathrm{IA}}$. The hypothesis was therefore rejected. These results are the first to directly show higher benthic respiration of $\mathrm{C}_{\mathrm{PP}}$ than $\mathrm{C}_{\mathrm{IA}}$ in the Arctic Ocean.

The background SCOC measurements in LS (2.4 mmol $\mathrm{m}_{2} \mathrm{~m}^{-2} \mathrm{~d}^{-1}$ ) and NOW (4.0 mmol $\mathrm{O}_{2} \mathrm{~m}^{-2}$ $\mathrm{d}^{-1}$ ) are in good agreement with the previously measured rates of 1-4 mmol $\mathrm{O}_{2} \mathrm{~m}^{-2} \mathrm{~d}^{-1}$ (LS) and 1-5+ mmol $\mathrm{O}_{2} \mathrm{~m}^{-2} \mathrm{~d}^{-1}$ (NOW) (Grant et al. 2002, Link et al. 2013b). SCOC is thought to be highest in the nutrient-rich Arctic inflow and interior shelves with high primary productivity, whereas in outflow shelves like the Canadian Arctic Archipelago, the mean sediment oxygen demand is $3.9 \mathrm{mmol} \mathrm{O}_{2} \mathrm{~m}^{-2}$ $\mathrm{d}^{-1}$ (Bourgeois et al. 2017). However, the SCOC in NOW and LS exceed the rates that could be expected in the Arctic for depths $>500 \mathrm{~m}$ (Clough et al. 2005, Grebmeier et al. 2006a, Bourgeois et al. 2017), suggesting that both sites are hotspots for deep-sea respiration in the Canadian Arctic (Link et al. 2011, 2013b). Our measurements were taken during the productive summer period, as the main algal blooms in LS occur in May-June (ice algae) and July-August (phytoplankton) (Michel et al. 2006) and May-June in NOW (Klein et al. 2002, Tremblay et al. 2002). Although maximum POC export in NOW occurs in May-June (Klein et al. 2002, Michel et al. 2002, Sampei et al. 2004), some export of particles to the seafloor also occurs in August (Amiel et al. 2002, Caron et al. 2004, Ardyna et al. 2011). This is then reflected in the SCOC, with highest values recorded in July-September (Grant et al. 2002, Link et al. 2013b). Our measurements therefore represent typical summertime SCOC.

Previous studies have found that a pulse of phytodetritus reaching the seafloor after spring or summer algal blooms can induce a peak in benthic respiration (Rysgaard et al. 1998, Renaud et al. 2007b, Bourgeois et al. 2017), but the phytodetritus addition during our experiments did not appear to significantly impact the SCOC. In NOW, no differences in SCOC were found between control, ice algal and phytoplankton cores, and similarly in LS, the SCOC in neither algal-amended cores was different from the background values. The differences between phytoplankton and ice algal core SCOC cannot therefore be attributed to the algal addition. As our measurements were taken at a time when SCOC rates in NOW and LS are usually at their annual peak, it is possible that the effect of the algal addition was masked by the already high background SCOC. The sediment C:N ratio (6.5 at both sites) and organic matter (10-11\%) and chl a (13-21 mg dry weight $\mathrm{m}^{-2}$ ) contents recorded at NOW and LS during sampling indeed suggest recent deposition of labile organic matter (Mäkelä et al. 2017b). A similar dampening effect has also been suggested by Sun et al. (2007), who observed algal addition to have no marked effect on SCOC in Smeerenburg Fjord, Svalbard, where the sediments had a high initial organic matter loading and surface sediment chl a content of $<2.5 \mu \mathrm{g} \mathrm{g}^{-1}$ dry 
sediment. Conversely, in the extremely food-limited HAUSGARTEN deep-sea observatory, Hoffmann et al. (2017) found that addition of both ice algae and phytoplankton increased the bacterial community oxygen consumption compared to the background values, but no difference between the algal types was found. Their experiment took place in JulyAugust, at the onset of the settling summer phytoplankton bloom, when the sediment organic carbon content was already sufficient to meet the energetic needs of the bacterial community (Hoffmann et al. 2017).

Our hypothesis on preferential ice algal respiration was derived from 2 experiments, which showed that ice algae significantly stimulate SCOC, whereas phytoplankton deposition did not increase the SCOC compared to background measurements (McMahon et al. 2006, Sun et al. 2007). The experiment by Sun et al. (2007) was carried out in the Storfjord Trench in Barents Sea during May, when the sediments contained a low initial content of labile organic matter (indicating pre-bloom/algal deposition conditions). On the other hand, McMahon et al. (2006) conducted their experiment in Ny Ålesund, Svalbard, in July-August, after the peak sedimentation in April-May (Hodal et al. 2012, Lalande et al. 2016). The diverse results from these experimental studies conducted during different bloom stages suggests that the SCOC after algal deposition is not solely driven by community 'readiness' or 'priming' due to amount or type of preexisting sediment organic matter.

However, using SCOC to investigate the responses of benthic communities to ice algae and phytoplankton has several limitations. Firstly, although $\mathrm{SCOC}$ is commonly used to measure benthic $\mathrm{C}$ respiration, it can be a poor representation of nutrient fluxes and DIC release due to high local variability in environmental and community compositions (Bühring et al. 2006b, Link et al. 2013a). Secondly, anaerobic mineralization is often stimulated during periods of high organic matter supply (Ferguson et al. 2003), and as SCOC does not take anaerobic processes into account, measurements derived from SCOC should be considered as minimum values for sediment $C$ respiration (Moran et al. 2005). Most importantly, when the total sediment respiration rates, calculated from the SCOC, were compared to the algal-derived respiration, only $30-60 \%$ of the respiration could be explained by the introduction of algae in our experiments. This proportion is notably higher than the $2.4-25 \%$ recorded during other isotope labelling in deep-sea sediments
(Moodley et al. 2002, Bühring et al. 2006a, Gontikaki et al. 2012). The changes in SCOC not attributed to the added phytodetritus could be due labile organic matter triggering the priming effect (Guenet et al. 2010), contributing to further respiration of existing refractory organic matter in the sediments, instead of the introduced algae. On the other hand, algal-derived respiration can also exceeded the total sediment respiration (Bühring et al. 2006b), suggesting a disconnect between SCOC and newly deposited organic matter respiration measurements. Clearly elevated respiration of added $\mathrm{C}$ can, however, be revealed through isotope labelling even in cases where the SCOC suggested an arrested benthic respiration (Moodley et al. 2005, Mayor et al. 2012a). For example, in the Northeast Atlantic, 300\% higher respiration of high-quality diatoms than poor-quality faecal pellets was recorded through $\mathrm{DI}^{13} \mathrm{C}$ release, but no difference in the SCOC between the treatments was found (Mayor et al. 2012a). We therefore argue that comparing the algal-derived DIC release rates is a more robust method for investigating the impact of specific $C$ sources (here $\mathrm{C}_{\mathrm{IA}}$ and $\mathrm{C}_{\mathrm{PP}}$ ) on benthic respiration, whereas SCOC gives an insight into the overall sediment community functioning and $\mathrm{C}$ demand.

\section{Bacterial responses to $\mathrm{C}_{\mathrm{PP}}$ and $\mathrm{C}_{\mathrm{IA}}$ addition}

We originally hypothesized that bacterial assimilation of $\mathrm{C}_{\mathrm{IA}}$ would be higher than assimilation of $\mathrm{C}_{\mathrm{PP}}$. The bacterial assimilation of added algae was rapid in all cores, with $\mathrm{C}_{\mathrm{PP}}$ and $\mathrm{C}_{\mathrm{IA}}$ uptake of 110 vs. $59 \mathrm{mg} \mathrm{C} \mathrm{m}^{-2}$ in NOW and 34 vs. $22 \mathrm{mg} \mathrm{C}$ $\mathrm{m}^{-2}$ in LS, respectively, but no significant differences between the treatments were found at either site, leading us to reject the original hypothesis. However, the total bacterial respiration of $C_{\mathrm{PP}}$ was higher than respiration of $\mathrm{C}_{\mathrm{IA}}$ at both sites. As the sediment bacterial biomass was higher in NOW than LS, probably due to greater food availability supporting a more diverse and abundant bacterial community in NOW (Boetius \& Damm 1998, Bienhold et al. 2012), we also calculated the biomassspecific uptake and respiration of $\mathrm{C}_{\mathrm{PP}}$ and $\mathrm{C}_{\mathrm{IA}}$ by the bacteria. The biomass-specific uptake in NOW (44-85 mg C g ${ }^{-1}$ ) was higher than in LS (22-26 mg $\mathrm{C}^{-1}$ ), but no difference between the treatments was observed. Also, the biomass-specific respiration was higher in NOW (26-33 $\mathrm{mg} \mathrm{C} \mathrm{g}^{-1}$ ) than LS (10-13 $\left.\mathrm{mg} \mathrm{C} \mathrm{g}^{-1}\right)$, with significantly more $C_{P P}$ than 
$\mathrm{C}_{\mathrm{IA}}$ being respired in NOW. The differences in the uptake and respiration efficiencies of the bacterial communities between the 2 sites could be due to higher absolute dose of algae added to the cores in NOW than LS, as food quantity is known to enhance benthic community activity and organic matter processing (Morata et al. 2015).

Contrary to our study, Sun et al. (2007) reported no significant assimilation of the ${ }^{13} \mathrm{C}$-labelled ice algae into bacterial biomass during their incubation experiments in the Barents Sea, whereas in similar experiments in Kotzebue Sound in Alaska, direct bacterial uptake of ice algae was recorded (Sun et al. 2009). These differences were suggested to be due to the depth difference between the sampling sites (10 vs. $260 \mathrm{~m}$, no incorporation was seen at the deeper site), core preparation (in intact cores, no uptake was found, whereas in homogenized sediment cores, uptake was high), differences in microbial communities or incubation temperatures, or age of the algal material (Sun et al. 2009). As rapid assimilation of algal $\mathrm{C}$ was seen in both NOW and LS, which are $>700 \mathrm{~m}$ deep, water depth is unlikely to inhibit bacterial uptake of algal C. Additionally, as uptake was immediate in our cores, which were undisturbed and received relatively fresh algae, these factors are unlikely to limit bacterial uptake of phytodetritus. The enzymatic and uptake capabilities of bacterial communities do, however, seem to impact their processing of different types of organic matter (Arnosti 2004, Hoffmann et al. 2017). Additionally, the organic matter source available can shape bacterial community structure (Boetius \& Lochte 1996, Kanzog et al. 2009, Hoffmann et al. 2017), indicating that organic matter quality can be a major driver for deep-sea bacterial diversity and $\mathrm{C}$ turnover.

Bacterial growth was stimulated by the algal addition, and in NOW, the bacterial biomass in both ice algal and phytoplankton cores was significantly higher than in the background cores at the end of the experiment. No difference between the 2 algal treatments was found, suggesting that the type of organic matter introduced was not a limiting factor for bacterial growth. It should be noted that bacterial production is often slower than bacterial respiration (Kritzberg et al. 2010) and therefore the effect of algal type on bacterial assimilation and growth could have been underestimated during these $4 \mathrm{~d}$ experiments. Nevertheless, our experiments are in agreement with the findings of Hoffmann et al. (2017), who reported that both ice algae and phytoplankton increased the sediment bacterial biomass, calculated from cell densities, compared to background cores. Bacterial growth efficiency is considered an indication of the fate of organic carbon, with higher growth efficiency implying that more $\mathrm{C}$ remains in organic form available to higher trophic levels, instead of being respired (Findlay et al. 2015). The calculated bacterial growth efficiency did not greatly vary between the sites or the algal treatments, but the values (0.36-0.46) confirm high investment into bacterial growth. The bacterial growth efficiencies here are in agreement with the typical range reported during incubation experiments with added diatoms in intertidal and deep-sea environments (Mayor et al. $2012 a, b)$, demonstrating that the bacterial growth efficiency is stimulated by the addition of a labile C source (del Giorgio \& Cole 1998). Our values are generally higher than those measured at the HAUSGARTEN deep-sea observatory, where addition of ice algal and phytoplankton material resulted in an estimated bacterial growth efficiency of $0.18-$ 0.42 (Hoffmann et al. 2017). The addition of faecal pellets and chitin have been shown to increase the bacterial growth efficiency more than fresh algae (Mayor et al. 2012a, Hoffmann et al. 2017), as POC transformed by the digestive system of zooplankton grazers is more bioavailable for bacteria in the environment (Witte et al. 2003b). This suggests that the quality of organic matter could impact its processing by bacteria, with the more degraded food items being favoured.

\section{Total processing of $\mathrm{C}_{\mathrm{PP}}$ and $\mathrm{C}_{\mathrm{IA}}$}

The total C processed, encompassing the algalderived DIC release, bacterial assimilation and macrofaunal uptake, was higher in phytoplankton than ice algal cores at both sites. As the dose of algae added to the experimental cores can impact the $\mathrm{C}$ processing rates, with a higher dose of organic matter triggering a stronger benthic response (Bühring et al. 2006b, Mayor et al. 2012b, Morata et al. 2015), the absolute amounts of $\mathrm{C}$ processed at LS and NOW could not be directly compared. However, the percentage of the added algae processed by the benthic communities suggests similar processing efficiency between our 2 study sites: in NOW, the benthic community processed 12.1 and $16.8 \%$ of the added $\mathrm{C}_{\mathrm{IA}}$ and $\mathrm{C}_{\mathrm{PP}}$, whereas in LS the community processed $9.2 \%\left(\mathrm{C}_{\mathrm{IA}}\right)$ and $13.5 \%\left(\mathrm{C}_{\mathrm{PP}}\right)$. The total amounts of added $\mathrm{C}$ processed per hour $\left(1.9-2.6 \mathrm{mg} \mathrm{C} \mathrm{m}^{-2} \mathrm{~h}^{-1}\right.$ in NOW and $0.6-0.8 \mathrm{mg} \mathrm{C} \mathrm{m}^{-2} \mathrm{~h}^{-1}$ in LS) fall within 
the $0.24-3.75 \mathrm{mg} \mathrm{C} \mathrm{m}^{-2} \mathrm{~h}^{-1}$ range recorded during other isotope tracing experiments at depths $>100 \mathrm{~m}$ (Woulds et al. 2016 and references therein). The percentage of the added algae processed at both sites is generally higher than what has been reported from other short-term isotope tracing experiments conducted in Atlantic abyssal plains (Gontikaki et al. 2011a, 2012, Mayor et al. 2012a), where the bottom water temperatures are close to, or below, $0^{\circ} \mathrm{C}$. The processing rates in NOW and LS are thus comparable to measurements from warmer regions, despite water temperature being a known limiting factor for C processing at the seafloor (Woulds et al. 2016 and references therein).

Respiration was the main pathway for both $\mathrm{C}_{\mathrm{IA}}$ and $\mathrm{C}_{\mathrm{PP}}$ processing, contributing $53-62 \%$ to the overall $\mathrm{C}$ processing in the cores. This is unsurprising, as the majority of the POC that is processed by the benthos in Arctic shelves is respired and released back into the water column (Graf et al. 1995, Macdonald et al. 1998, Findlay et al. 2015). Additionally, previous deep sea isotope labelling experiments have shown that $45-96 \%$ of the processed ${ }^{13} \mathrm{C}$-labelled phytodetritus was respired (Moodley et al. 2002, Witte et al. 2003a, Woulds et al. 2009, Gontikaki et al. 2011b, 2012). Indeed, the $\mathrm{C}_{\mathrm{IA}}$ and $\mathrm{C}_{\mathrm{PP}}$ respiration rates in NOW $\left(1.2\right.$ and $1.4 \mathrm{mg} \mathrm{C} \mathrm{m}^{-2}$ $\mathrm{h}^{-1}$ ) and LS (0.3 and $\left.0.4 \mathrm{mg} \mathrm{C} \mathrm{m}{ }^{-2} \mathrm{~h}^{-1}\right)$ fall within the typical range of $0.1-2.8 \mathrm{mg} \mathrm{C} \mathrm{m}^{-2} \mathrm{~h}^{-1}$ recorded during other deep-sea isotope tracing experiments (Woulds et al. 2009 and references therein). In all cores, the vast majority ( $>90 \%$ ) of the respiration of $\mathrm{C}_{\mathrm{IA}}$ and $\mathrm{C}_{\mathrm{PP}}$ was attributed to the sediment bacteria. Bacterial uptake of $\mathrm{C}_{\mathrm{IA}}$ and $\mathrm{C}_{\mathrm{PP}}$ was also significant, with $33-44 \%$ of the total $\mathrm{C}$ processing directed towards bacterial assimilation and growth, which was also illustrated by the high bacterial growth efficiency and rapid increase in bacterial biomass after algal additions. Interestingly, despite the high macroinfaunal biomass and density at both LS and NOW (Mäkelä et al. 2017b), the role of these fauna, mainly polychaetes and crustaceans in NOW and polychaetes and bivalves in LS, in the processing of $\mathrm{C}_{\mathrm{IA}}$ and $\mathrm{C}_{\mathrm{PP}}$ was negligible. However, the overall biological processing in neither LS nor NOW seems to correspond with the categories of labelled C processing patterns identified by Woulds et al. (2009, 2016). These categories include (1) respiration domination, where $>75 \%$ of $\mathrm{C}$ processing is through respiration, (2) active faunal uptake, where $<75 \%$ of $\mathrm{C}$ is respired and macrofauna, foraminifera and bacteria contribute $10-25 \%$ to $\mathrm{C}$ uptake, (3) metazoan and macrofaunal uptake dominated and (4) bacteria uptake dominated, where bacterial uptake is the main $\mathrm{C}$ processing pathway. As in NOW and LS, C processing was driven by bacteria, but was not dominated by bacterial uptake or characterized by $>75 \%$ respiration; the processing could thus best be characterized by both active bacterial respiration and uptake.

If we assume that the proportions of added $\mathrm{C}$ respired by different benthic actors can also be applied to SCOC (Gontikaki et al. 2011a), the majority of short-term sediment $\mathrm{C}$ turnover in LS and NOW was due to bacterial activities. It should be noted that the meio- and megafaunal contributions to the sediment $\mathrm{C}$ turnover were not assessed during these experiments, and while the role of meiofauna is likely to be small (Piepenburg et al. 1995, Heip et al. 2001, Gontikaki et al. 2011a), megafaunal respiration can be significant on a local scale (Piepenburg et al. 1995, Piepenburg \& Schmid 1996, Ambrose et al. 2001). Still, bacteria can dominate benthic respiration in the Arctic deep sea (Piepenburg et al. 1995, van Oevelen et al. 2011), while macrofauna tend to be more important in shallower depths (Rowe et al. 1997, Clough et al. 2005, Renaud et al. 2007b). Furthermore, macrofauna dominate SCOC in NOW during summer, whereas the meio-microbial component was more significant during the spring (Grant et al. 2002). Our results, however, indicate that bacteria also dominate the benthic $\mathrm{C}$ respiration during summer.

It is important to note that the results of this study only provide a snapshot of the immediate community $\mathrm{C}$ processing, and as an excessive amount of algae was added to the cores, the results reflect the maximum processing efficiency of the benthic communities. In experiments where an artificial bloom of organic matter has been introduced to the seafloor, the majority of the activity (uptake and respiration) occurred immediately after the food pulse (Aberle \& Witte 2003, Gontikaki et al. 2011a), and often within 1-3 wk, the algal consumption and respiration returned to background levels (McMahon et al. 2006, Sun et al. 2007). Therefore, drawing conclusions on long-term $\mathrm{C}$ cycling based on these results must be done with caution, as they can easily overestimate the rates of processes (Woulds et al. 2009). Furthermore, the incubation temperature $\left(4^{\circ} \mathrm{C}\right)$ was slightly higher than the ambient temperature at the seafloor, which may have affected processing rates (Renaud et al. 2007a, Morata et al. 2015). However, as the temperature was the same for all incubation cores, it does not affect the experimental design and testing 
of the hypotheses themselves. It should also be noted that bacteria and macroinfauna have very limited mobility, and as ice algae often sink to the seafloor in patchy aggregations and not in an evenly distributed rain of cells like phytoplankton do, the smaller size classes of benthic consumers may not have similar access to ice algae as highly mobile consumers do (Iken et al. 2001, MacDonald et al. 2010, Mäkelä et al. $2017 b)$. This agrees with the observations by Boetius et al. (2013), who showed that only mobile megafauna and possibly bacteria used ice algal patches as a food source in the central Arctic Ocean. Phytodetritus patchiness could thus impact the benthic $\mathrm{C}$ cycle on a large spatial scale, as the access of small benthic consumers to ice algae might be more restricted and localized.

\section{Reconciling benthic $\mathrm{C}$ supply and demand}

A longer open water period is thought to increase the oceanic drawdown of $\mathrm{CO}_{2}$ (Bates et al. 2006), and consequently the importance of Arctic sediments as sites of C sequestration (McGuire et al. 2010, Findlay et al. 2015, Harada 2016). To estimate what fraction of the exported POC is respired by the benthic communities and how much is ultimately buried in the sediments, the POC supply and benthic $\mathrm{C}$ demand must be compared. As our experiments only reveal the initial responses of benthos to algal deposition, we did not attempt to extrapolate the results to represent the annual benthic $\mathrm{C}$ cycle, but rather relate the measurements to the daily rates of PP and $\mathrm{C}$ export during peak bloom times.

The rates of phytoplankton POC production during the spring-summer period in NOW are on average 1.1-1.7 $\mathrm{g} \mathrm{C} \mathrm{m}^{-2} \mathrm{~d}^{-1}$, but can reach rates of up to 4.4-5.0 $\mathrm{g} \mathrm{C} \mathrm{m}^{-2} \mathrm{~d}^{-1}$ (Klein et al. 2002, Mei et al. 2003). In LS, rates of $\mathrm{C}$ production range between 0.8 and $1.2 \mathrm{~g} \mathrm{C} \mathrm{m}^{-2} \mathrm{~d}^{-1}$ during peak bloom times (Sameoto et al. 1986) or $0.25 \mathrm{~g} \mathrm{C} \mathrm{m}^{-2} \mathrm{~d}^{-1}$ during the whole summer period (Ardyna et al. 2011). The benthic $\mathrm{C}$ demand, calculated from SCOC, was 39-56 $\mathrm{mg} \mathrm{C} \mathrm{m}^{-2} \mathrm{~d}^{-1}$ in NOW and $15-36 \mathrm{mg} \mathrm{C} \mathrm{m}^{-2} \mathrm{~d}^{-1}$ in LS. This responds to $<1$ to $5 \%$ of the daily PP in NOW (Klein et al. 2002, Mei et al. 2003), and 3-14\% in LS (Sameoto et al. 1986, Ardyna et al. 2011). Tremblay et al. (2006) estimated that 7 and $1 \%$ of POC in NOW reaches depths of 200 and $500 \mathrm{~m}$, respectively, whereas Hamel et al. (2002) estimated from long-term accumulation of C into sediments that $4-6 \%$ of annual PP sinks to the seafloor. In NOW, the benthic $\mathrm{C}$ demand thus seems to be in good agreement with the estimated export flux, suggesting that the benthic $\mathrm{C}$ demand and supply are in good balance at peak algal bloom times. Grant et al. (2002) reported, similar to us, the benthic $\mathrm{C}$ demand in NOW to be $\sim 50 \mathrm{mg} \mathrm{C} \mathrm{m}^{-2} \mathrm{~d}^{-1}$ (Klein et al. 2002). They were, however, able to compare the benthic $\mathrm{C}$ demand to the POC flux recorded by Hargrave et al. (2002) during the same time period, concluding that the benthic $\mathrm{C}$ demand exceeded the supply by 5-40 times at 2 locations, whereas at 1 site, the rates matched fairly well (Grant et al. 2002). Still, the inter-annual variability in flux estimates is high, as a 2-5 times increase in POC fluxes from 19971998 to 1998-1999 in NOW was reported (Hargrave et al. 2002). This high spatial and temporal variability makes it difficult to detect possible long-term changes to benthic $\mathrm{C}$ budgets.

If we estimate that similarly to NOW, $1-6 \%$ of the daily PP sinks to the seafloor, the POC export in LS does not meet the calculated C turnover of $3-14 \%$ of the PP. There is therefore a potential mismatch between the $\mathrm{C}$ supply and demand in LS, suggesting the benthos might rely on allochthonous $\mathrm{C}$ sources to meet their energetic needs. A similar discrepancy has also been recorded in in the Amundsen Gulf, where the Cape Bathurst Polynya, which is the reference site for POC export for LS, is located. In the Amundsen Gulf, the sinking flux supplies only $60 \%$ of the benthic $\mathrm{C}$ demand, and other $\mathrm{C}$ sources within the benthic boundary layer are needed to fuel the benthic activities (Forest et al. 2011). Current velocities in LS are known to be some of the highest recorded in the Canadian Arctic (Thomson 1982), which could enable lateral supply of organic matter from outside the study site, helping the benthos meet their $\mathrm{C}$ demand. In the absence of any POC export data from LS, the discussion on how well the $\mathrm{C}$ supply meets the demand is highly speculative, and illustrates a need for particle trap studies in the region.

These experiments show that during summer, the benthic C demand in NOW and LS either closely matches or exceeds the POC supply, and the high respiration rates render the sediments as sources, rather than sinks, of $\mathrm{CO}_{2}$. Climate change can have an unpredictable impact on the benthic $\mathrm{C}$ budgets through changes in $\mathrm{C}$ supply and demand. While novel under-ice (Mundy et al. 2009, 2014, Lowry et al. 2014, Assmy et al. 2017) and autumn (Brugel et al. 2009, Ardyna et al. 2011, 2014) phytoplankton blooms or possible mismatch of the blooms and zooplankton reproduction (Søreide et al. 2010, Leu et al. 2011) have the potential to increase POC export to the seafloor, increased zooplankton biomass and 
grazing due to warm surface water temperatures could significantly reduce it (Coyle \& Pinchuk 2002, Hunt et al. 2002). Additionally, C export to the seafloor could be altered if future conditions in the Arctic Ocean favour the growth of picoplankton species at the expense of larger nanoplankton (Li et al. 2009, Tremblay et al. 2012, Blais et al. 2017), or benefit Phaeocystis pouchetii instead of diatoms (Lovejoy et al. 2004). Benthos may thus struggle to meet their energetic needs if POC export to the seafloor decreases, or if their $\mathrm{C}$ demand increases with increased food availability (Morata et al. 2015) or due to the transition from ice algal to phytoplankton organic matter (this study). It should be noted that as only axenic cultures of Synedropsis hyperborea and Thalassiosira nordenskioeldii were used to represent ice algal and phytoplankton communities in this study, it is difficult to assess to which extent the patterns observed are dependent on the algal species used. Future work should therefore focus on how the species composition of ice algal and phytoplankton communities impacts the C cycling rates described here. As S. hyperborea and $T$. nordenskioeldii are among the most commonly encountered ice algal and phytoplankton species, respectively (Hegseth 1998, Lovejoy et al. 2002, von Quillfeldt et al. 2003, Tamelander et al. 2009), we are confident that the conclusions of this study also apply in situ. Finally, while some $\mathrm{C}$ budgets have been calculated for the Arctic Ocean (Hirche et al. 2006, Tremblay et al. 2006, Wassmann et al. 2006, 2008, Forest et al. 2011), the seafloor component is often reduced to only downward POC export, despite the active role sediment communities have in $\mathrm{C}$ respiration. We therefore highlight the need for better integration of benthic $\mathrm{C}$ cycling processes to Arctic biogeochemical models.

\section{CONCLUSIONS}

Climate change has the potential to alter Arctic benthic $\mathrm{C}$ cycling through changes to timing, quality and quantity of POC exported to the seafloor. The present study tested the hypothesis that ice algae are the preferred $\mathrm{C}$ source for benthic communities, and therefore $\mathrm{C}_{\mathrm{IA}}$ is more readily processed by the benthos in LS and NOW than $\mathrm{C}_{\mathrm{PP}}$. Contrary to previous studies and our hypothesis, the processing rate of the phytoplankton species Thalassiosira nordenskioeldii was higher than that of the ice algal species Synedropsis hyperborea at both sites. The main pathway for processing of the added $\mathrm{C}$ was respiration, with
18-34\% higher respiration of $\mathrm{C}_{\mathrm{PP}}$ than $\mathrm{C}_{\mathrm{IA}}$. The sediment community oxygen consumption, indicative of the total sediment $C$ respiration, was not significantly changed by the algal addition, suggesting that this method is not sensitive enough to detect the impact of different $\mathrm{C}$ sources on sediment respiration. Bacteria rapidly and non-preferentially incorporated both $\mathrm{C}_{\mathrm{IA}}$ and $\mathrm{C}_{\mathrm{PP}}$, and bacterial biomass was rapidly increased following addition of both algal types. Overall, 33 and $37 \%$ higher processing of $\mathrm{C}_{\mathrm{PP}}$ than $\mathrm{C}_{\mathrm{IA}}$ was recorded in NOW and in LS, respectively. During the peak summer growth season, the total daily sediment $\mathrm{C}$ demand either closely matched or exceeded the estimated POC supply, suggesting the sediments are unlikely to act as major $\mathrm{C}$ sinks at this time due to high water column retention and increased benthic $\mathrm{C}$ turnover. However, as the type of sinking phytodetritus appears to influence the $\mathrm{C}$ residence time at the seafloor, the future changes to magnitude and quality of POC sinking to the seafloor could influence the proportions of $\mathrm{C}$ being remineralized and sequestered.

Acknowledgements. We thank the officers and crew of the CCGS 'Amundsen' and the ArcticNet scientific and technical personnel for support onboard, and C. Grant (Université Laval) and G. Kazanidis (University of Aberdeen) for field assistance. Additional thanks go to V. Johnston (University of Aberdeen) for general lab assistance. Work was supported by University of Aberdeen The North theme funding for A.M., Natural Environment Research Council ArcDEEP project grant NE/J023094 awarded to U.W. and ArcticNet and Green Edge (Takuvik) funding to P.A.

\section{LITERATURE CITED}

Aberle N, Witte U (2003) Deep-sea macrofauna exposed to a simulated sedimentation event in the abyssal NE Atlantic: in situ pulse-chase experiments using ${ }^{13} \mathrm{C}$-labelled phytodetritus. Mar Ecol Prog Ser 251:37-47

Ambrose WG Jr, Renaud PE (1995) Benthic response to water column productivity patterns: evidence for benthic-pelagic coupling in the Northeast Water Polynya. J Geophys Res 100:4411-4421

Ambrose WG Jr, Clough L, Tilney P, Beer L (2001) Role of echinoderms in benthic remineralization in the Chukchi Sea. Mar Biol 139:937-949

Amiel D, Cochran JK, Hirschberg DJ (2002) ${ }^{234} \mathrm{Th} /{ }^{238} \mathrm{U}$ disequilibrium as an indicator of the seasonal export flux of particulate organic carbon in the North Water. Deep-Sea Res II 49:5191-5209

Ardyna M, Gosselin M, Michel C, Poulin M, Tremblay JÉ (2011) Environmental forcing of phytoplankton community structure and function in the Canadian High Arctic: contrasting oligotrophic and eutrophic regions. Mar Ecol Prog Ser 442:37-57

Ardyna M, Babin M, Gosselin M, Devred E, Rainville L, 
Tremblay JÉ (2014) Recent Arctic Ocean sea ice loss triggers novel fall phytoplankton blooms. Geophys Res Lett 41:6207-6212

Arnosti C (2004) Speed bumps and barricades in the carbon cycle: substrate structural effects on carbon cycling. Mar Chem 92:263-273

* Arrigo KR, van Dijken GL (2015) Continued increases in Arctic Ocean primary production. Prog Oceanogr 136: 60-70

Arrigo KR, van Dijken GL, Pabi S (2008) Impact of a shrinking Arctic ice cover on marine primary production. Geophys Res Lett 35:L19603

Assmy P, Ehn JK, Fernández-Méndez M, Hop H and others (2013) Floating ice-algal aggregates below melting Arctic sea ice. PLOS ONE 8:e76599

Assmy P, Fernández-Méndez M, Duarte P, Meyer A and others (2017) Leads in Arctic pack ice enable early phytoplankton blooms below snow-covered sea ice. Sci Rep 7:40850

Bates NR, Moran SB, Hansell DA, Mathis JT (2006) An increasing $\mathrm{CO}_{2}$ sink in the Arctic Ocean due to sea-ice loss. Geophys Res Lett 33:L23609

*élanger S, Babin M, Tremblay JÉ (2013) Increasing cloudiness in Arctic damps the increase in phytoplankton primary production due to sea ice receding. Biogeosciences 10:4087-4101

Bienhold C, Boetius A, Ramette A (2012) The energydiversity relationship of complex bacterial communities in Arctic deep-sea sediments. ISME J 6:724-732

Blais M, Ardyna M, Gosselin M, Dumont D and others (2017) Contrasting interannual changes in phytoplankton productivity and community structure in the coastal Canadian Arctic Ocean. Limnol Oceanogr 62: 2480-2497

Bligh EG, Dyer WJ (1959) A rapid method of total lipid extraction and purification. Can J Biochem Physiol 37: 911-917

Boetius A, Damm E (1998) Benthic oxygen uptake, hydrolytic potentials and microbial biomass at the Arctic continental slope. Deep-Sea Res I Oceanogr Res Pap 45:239-275

Boetius A, Lochte K (1996) Effect of organic enrichments on hydrolytic potentials and growth of bacteria in deep-sea sediments. Mar Ecol Prog Ser 140:239-250

Boetius A, Albrecht S, Bakker K, Bienhold C and others (2013) Export of algal biomass from the melting Arctic sea ice. Science 339:1430-1432

Boschker HTS, Middelburg JJ (2002) Stable isotopes and biomarkers in microbial ecology. FEMS Microbiol Ecol 40:85-95

Boschker HTS, Nold SC, Wellsbury P, Bos D and others (1998) Direct linking of microbial populations to specific biogeochemical processes by ${ }^{13} \mathrm{C}$-labelling of biomarkers. Nature 392:801-805

Bourgeois S, Archambault P, Witte U (2017) Organic matter remineralization in marine sediments: a Pan-Arctic synthesis. Global Biogeochem Cycles 31:190-213

Brinch-Iversen J, King GM (1990) Effects of substrate concentration, growth-state, and oxygen availability on relationships among bacterial carbon, nitrogen and phospholipid phosphorus-content. FEMS Microbiol Ecol 74: 345-355

Brugel S, Nozais C, Poulin M, Tremblay JÉ and others (2009) Phytoplankton biomass and production in the southeastern Beaufort Sea in autumn 2002 and 2003. Mar Ecol
Prog Ser 377:63-77

*Bühring SI, Ehrenhauss S, Kamp A, Moodley L, Witte U (2006a) Enhanced benthic activity in sandy sublittoral sediments: evidence from ${ }^{13} \mathrm{C}$ tracer experiments. Mar Biol Res 2:120-129

* Bühring SI, Lampadariou N, Moodley L, Tselepides A, Witte U (2006b) Benthic microbial and whole-community responses to different amounts of ${ }^{13} \mathrm{C}$-enriched algae: in situ experiments in the deep Cretan Sea (Eastern Mediterranean). Limnol Oceanogr 51:157-165

* Byrén L, Ejdung G, Elmgren R (2006) Uptake of sedimentary organic matter by the deposit-feeding Baltic amphipods Monoporeia affinis and Pontoporeia femorata. Mar Ecol Prog Ser 313:135-143

* Carmack E, Wassmann P (2006) Food webs and physicalbiological coupling on pan-Arctic shelves: unifying concepts and comprehensive perspectives. Prog Oceanogr 71:446-477

* Caron G, Michel C, Gosselin M (2004) Seasonal contributions of phytoplankton and fecal pellets to the organic carbon sinking flux in the North Water (northern Baffin Bay). Mar Ecol Prog Ser 283:1-13

Carroll ML, Carroll J (2003) The Arctic seas. In: Black K, Shimmield GB (eds) Biogeochemistry of marine systems. Blackwell Publishing, Oxford, p 127-156

* Clough LM, Renaud PE, Ambrose WG Jr (2005) Impacts of water depth, sediment pigment concentration, and benthic macrofaunal biomass on sediment oxygen demand in the western Arctic Ocean. Can J Fish Aquat Sci 62: 1756-1765

Coyle KO, Pinchuk AI (2002) Climate-related differences in zooplankton density and growth on the inner shelf of the southeastern Bering Sea. Prog Oceanogr 55: 177-194

del Giorgio PA, Cole JJ (1998) Bacterial growth efficiency in natural aquatic systems. Annu Rev Ecol Syst 29: $503-541$

D Dupont F (2012) Impact of sea-ice biology on overall primary production in a biophysical model of the pan-Arctic Ocean. J Geophys Res Oceans 117:C00D17

Evrard V, Soetaert K, Heip CHR, Huettel M, Xenopoulos MA, Middelburg JJ (2010) Carbon and nitrogen flows through the benthic food web of a photic subtidal sandy sediment. Mar Ecol Prog Ser 416:1-16

F Falk-Petersen S, Sargent JR, Henderson J, Hegseth EN, Hop H, Okolodkov YB (1998) Lipids and fatty acids in ice algae and phytoplankton from the Marginal Ice Zone in the Barents Sea. Polar Biol 20:41-47

FFerguson AJP, Eyre BD, Gay JM (2003) Organic matter and benthic metabolism in euphotic sediments along shallow sub-tropical estuaries, northern New South Wales, Australia. Aquat Microb Ecol 33:137-154

*Fernández-Méndez M, Wenzhöfer F, Peeken I, Sørensen HL, Glud RN, Boetius A (2014) Composition, buoyancy regulation and fate of ice algal aggregates in the Central Arctic Ocean. PLOS ONE 9:e107452

Fernández-Méndez M, Katlein C, Rabe B, Nicolaus M and others (2015) Photosynthetic production in the central Arctic Ocean during the record sea-ice minimum in 2012. Biogeosciences 12:3525-3549

Findlay HS, Gibson G, K dra M, Morata N and others (2015) Responses in Arctic marine carbon cycle processes: conceptual scenarios and implications for ecosystem function. Polar Res 34:24252 
Forest A, Tremblay JÉ, Gratton Y, Martin J and others (2011) Biogenic carbon flows through the planktonic food web of the Amundsen Gulf (Arctic Ocean): a synthesis of field measurements and inverse modeling analyses. Prog Oceanogr 91:410-436

Frey KE, Moore GWK, Cooper LW, Grebmeier JM (2015) Divergent patterns of recent sea ice cover across the Bering, Chukchi, and Beaufort seas of the Pacific Arctic Region. Prog Oceanogr 136:32-49

*Gontikaki E, Mayor DJ, Thornton B, Black K, Witte U (2011a) Processing of ${ }^{13} \mathrm{C}$-labelled diatoms by a bathyal community at sub-zero temperatures. Mar Ecol Prog Ser 421:39-50

Gontikaki E, van Oevelen D, Soetaert K, Witte U (2011b) Food web flows through a sub-arctic deep-sea benthic community. Prog Oceanogr 91:245-259

Gontikaki E, Polymenakou PN, Thornton B, Narayanaswamy BE, Black K, Tselepides A, Witte U (2012) Microbial response to organic matter enrichment in the oligotrophic Levantine Basin (Eastern Mediterranean). Geomicrobiol J 29:648-655

* Gooday AJ (2002) Biological responses to seasonally varying fluxes of organic matter to the ocean floor: a review. J Oceanogr 58:305-332

Gosselin M, Levasseur M, Wheeler PA, Horner RA, Booth BC (1997) New measurements of phytoplankton and ice algal production in the Arctic Ocean. Deep-Sea Res II 44: 1623-1644

Graf G, Gerlach SA, Linke P, Queisser W and others (1995) Benthic-pelagic coupling in the Greenland-Norwegian Sea and its effect on the geological record. Geol Rundsch 84:49-58

* Grant J, Hargrave BT, Macpherson P (2002) Sediment properties and benthic-pelagic coupling in the North Water. Deep-Sea Res II 49:5259-5275

Grasshoff K, Kremling K, Ehrhardt M (1999) Methods of seawater analysis, 3rd edn. Wiley-VCH Verlag, Weinheim

* Grebmeier JM, Cooper LW, Feder HM, Sirenko BI (2006a) Ecosystem dynamics of the Pacific-influenced Northern Bering and Chukchi Seas in the Amerasian Arctic. Prog Oceanogr 71:331-361

*Grebmeier JM, Overland JE, Moore SE, Farley EV and others (2006b) A major ecosystem shift in the northern Bering Sea. Science 311:1461-1464

* Guenet B, Danger M, Abbadie L, Lacroix G (2010) Priming effect: bridging the gap between terrestrial and aquatic ecology. Ecology 91:2850-2861

*Haecky P, Jonsson S, Andersson A (1998) Influence of sea ice on the composition of the spring phytoplankton bloom in the northern Baltic Sea. Polar Biol 20:1-8

* Hamel D, De Vernal A, Gosselin M, Hillaire-Marcel C (2002) Organic-walled microfossils and geochemical tracers: sedimentary indicators of productivity changes in the North Water and northern Baffin Bay during the last centuries. Deep-Sea Res II 49:5277-5295

* Harada N (2016) Potential catastrophic reduction of sea ice in the western Arctic Ocean: its impact on biogeochemical cycles and marine ecosystems. Global Planet Change 136:1-17

* Hargrave BT, Walsh ID, Murray DW (2002) Seasonal and spatial patterns in mass and organic matter sedimentation in the North Water. Deep-Sea Res II 49:5227-5244

Hegseth EN (1998) Primary production of the northern Barents Sea. Polar Res 17:113-123
*Heip CHR, Duineveld G, Flach E, Graf G and others (2001) The role of the benthic biota in sedimentary metabolism and sediment-water exchange processes in the Goban Spur area (NE Atlantic). Deep-Sea Res II 48:3223-3243

Hirche HJ, Kosobokova KN, Gaye-Haake B, Harms I, Meon B, Nöthig EM (2006) Structure and function of contemporary food webs on Arctic shelves: A panarctic comparison. The pelagic system of the Kara Sea-Communities and components of carbon flow. Prog Oceanogr 71: 288-313

Hodal H, Falk-Petersen S, Hop H, Kristiansen S, Reigstad M (2012) Spring bloom dynamics in Kongsfjorden, Svalbard: nutrients, phytoplankton, protozoans and primary production. Polar Biol 35:191-203

* Hoffmann K, Hassenrück C, Salman-Carvalho V, Holtappels M, Bienhold C (2017) Response of bacterial communities to different detritus compositions in arctic deep-sea sediments. Front Microbiol 8:266

*Hunt GL Jr, Stabeno P, Walters G, Sinclair E, Brodeur RD, Napp JM, Bond NA (2002) Climate change and control of the southeastern Bering Sea pelagic ecosystem. DeepSea Res II 49:5821-5853

* Hunter WR, Levin LA, Kitazato H, Witte U (2012) Macrobenthic assemblage structure and organismal stoichiometry control faunal processing of particulate organic carbon and nitrogen in oxygen minimum zone sediments. Biogeosciences 9:993-1006

* Hunter WR, Jamieson A, Huvenne VAI, Witte U (2013) Sediment community responses to marine vs. terrigenous organic matter in a submarine canyon. Biogeosciences 10:67-80

* Iken K, Brey T, Wand U, Voigt J, Junghans P (2001) Food web structure of the benthic community at the Porcupine Abyssal Plain (NE Atlantic): a stable isotope analysis. Prog Oceanogr 50:383-405

Jónasdóttir SH, Visser AW, Jespersen C (2009) Assessing the role of food quality in the production and hatching of Temora longicornis eggs. Mar Ecol Prog Ser 382: 139-150

Kanzog C, Ramette A, Quéric NV, Klages M (2009) Response of benthic microbial communities to chitin enrichment: an in situ study in the deep Arctic Ocean. Polar Biol 32:105-112

*Katlein C, Fernández-Méndez M, Wenzhöfer F, Nicolaus M (2015) Distribution of algal aggregates under summer sea ice in the Central Arctic. Polar Biol 38:719-731

Klein B, LeBlanc B, Mei ZP, Beret R and others (2002) Phytoplankton biomass, production and potential export in the North Water. Deep-Sea Res II 49:4983-5002

Kritzberg ES, Duarte CM, Wassmann P (2010) Changes in Arctic marine bacterial carbon metabolism in response to increasing temperature. Polar Biol 33:1673-1682

* Lalande C, Forest A, Barber DG, Gratton Y, Fortier L (2009) Variability in the annual cycle of vertical particulate organic carbon export on Arctic shelves: contrasting the Laptev Sea, Northern Baffin Bay and the Beaufort Sea. Cont Shelf Res 29:2157-2165

Lalande C, Moriceau B, Leynaert A, Morata N (2016) Spatial and temporal variability in export fluxes of biogenic matter in Kongsfjorden. Polar Biol 39:1725-1738

* Leu E, Søreide JE, Hessen DO, Falk-Petersen S, Berge J (2011) Consequences of changing sea-ice cover for primary and secondary producers in the European Arctic 
shelf seas: timing, quantity, and quality. Prog Oceanogr 90:18-32

Leu E, Mundy CJ, Assmy P, Campbell K and others (2015) Arctic spring awakening - steering principles behind the phenology of vernal ice algal blooms. Prog Oceanogr 139:151-170

* Li WKW, McLaughlin FA, Lovejoy C, Carmack EC (2009) Smallest algae thrive as the Arctic Ocean freshens. Science 326:539

Link H, Archambault P, Tamelander T, Renaud PE, Piepenburg D (2011) Spring-to-summer changes and regional variability of benthic processes in the western Canadian Arctic. Polar Biol 34:2025-2038

Link H, Chaillou G, Forest A, Piepenburg D, Archambault P (2013a) Multivariate benthic ecosystem functioning in the Arctic-benthic fluxes explained by environmental parameters in the southeastern Beaufort Sea. Biogeosciences 10:5911-5929

Link H, Piepenburg D, Archambault P (2013b) Are hotspots always hotspots? The relationship between diversity, resource and ecosystem functions in the Arctic. PLOS ONE 8:e74077

Lovejoy C, Legendre L, Martineau MJ, Bacle J, von Quillfeldt CH (2002) Distribution of phytoplankton and other protists in the North Water. Deep-Sea Res II 49: 5027-5047

Lovejoy C, Price NM, Legendre L (2004) Role of nutrient supply and loss in controlling protist species dominance and microbial food-webs during spring blooms. Aquat Microb Ecol 34:79-92

* Lowry KE, van Dijken GL, Arrigo KR (2014) Evidence of under-ice phytoplankton blooms in the Chukchi Sea from 1998 to 2012. Deep-Sea Res II 105:105-117

MacDonald IR, Bluhm BA, Iken K, Gagaev S, Strong S (2010) Benthic macrofauna and megafauna assemblages in the Arctic deep-sea Canada Basin. Deep-Sea Res II 57: 136-152

Macdonald RW, Solomon SM, Cranston RE, Welch HE, Yunker MB, Gobeil C (1998) A sediment and organic carbon budget for the Canadian Beaufort Shelf. Mar Geol 144:255-273

Main CE, Ruhl HA, Jones DOB, Yool A, Thornton B, Mayor DJ (2015) Hydrocarbon contamination affects deep-sea benthic oxygen uptake and microbial community composition. Deep-Sea Res I Oceanogr Res Pap 100:79-87

Mäkelä A, Witte U, Archambault P (2017a) Ice algae vs. phytoplankton: resource utilization by Arctic deep sea macroinfauna revealed through isotope labelling experiments. Mar Ecol Prog Ser 572:1-18

Mäkelä A, Witte U, Archambault P (2017b) Benthic macroinfaunal community structure, resource utilisation and trophic relationships in two Canadian High Arctic polynyas. PLOS ONE 12:e0183034

Manizza M, Follows MJ, Dutkiewicz S, Menemenlis D, Hill CN, Key RM (2013) Changes in the Arctic Ocean $\mathrm{CO}_{2}$ sink (1996-2007): a regional model analysis. Global Biogeochem Cycles 27:1108-1118

Matrai P, Apollonio S (2013) New estimates of microalgae production based upon nitrate reductions under sea ice in Canadian shelf seas and the Canada Basin of the Arctic Ocean. Mar Biol 160:1297-1309

Mayor DJ, Thornton B, Hay S, Zuur AF, Nicol GW, McWilliam JM, Witte U (2012a) Resource quality affects carbon cycling in deep-sea sediments. ISME $\mathrm{J}$ 6: 1740-1748

*Mayor DJ, Thornton B, Zuur AF (2012b) Resource quantity affects benthic microbial community structure and growth efficiency in a temperate intertidal mudflat. PLOS ONE $7: \mathrm{e} 38582$

*McGuire AD, Hayes DJ, Kicklighter DW, Manizza M and others (2010) An analysis of the carbon balance of the Arctic Basin from 1997 to 2006. Tellus Ser B Chem Phys Meteorol 62:455-474

*McMahon KW, Ambrose WG Jr, Johnson BJ, Sun MY, Lopez GR, Clough LM, Carroll ML (2006) Benthic community responses to ice algae and phytoplankton in Ny Ålesund, Svalbard. Mar Ecol Prog Ser 310:1-14

*Mei ZP, Legendre L, Gratton Y, Tremblay JÉ, LeBlanc B, Klein B, Gosselin M (2003) Phytoplankton production in the North Water Polynya: size-fractions and carbon fluxes, April to July 1998. Mar Ecol Prog Ser 256:13-27

Michel C, Gosselin M, Nozais C (2002) Preferential sinking export of biogenic silica during the spring and summer in the North Water Polynya (northern Baffin Bay): temperature or biological control? J Geophys Res 107:1-14

Michel C, Ingram RG, Harris LR (2006) Variability in oceanographic and ecological processes in the Canadian Arctic Archipelago. Prog Oceanogr 71:379-401

* Middelburg JJ, Barranguet C, Boschker HTS, Herman PMJ, Moens T, Heip CHR (2000) The fate of intertidal microphytobenthos carbon: an in situ ${ }^{13} \mathrm{C}$-labeling study. Limnol Oceanogr 45:1224-1234

Moodley L, Middelburg JJ, Boschker HTS, Duineveld GCA, Pel R, Herman PMJ, Heip CHR (2002) Bacteria and Foraminifera: key players in a short term deep-sea benthic response to phytodetritus. Mar Ecol Prog Ser 236: 23-29

Moodley L, Middelburg JJ, Soetaert K, Boschker HTS, Herman PMJ, Heip CHR (2005) Similar rapid response to phytodetritus deposition in shallow and deep-sea sediments. J Mar Res 63:457-469

*Moran SB, Kelly RP, Hagstrom K, Smith JN and others (2005) Seasonal changes in POC export flux in the Chukchi Sea and implications for water column-benthic coupling in Arctic shelves. Deep-Sea Res II 52: 3427-3451

Morata N, Renaud PE (2008) Sedimentary pigments in the western Barents Sea: a reflection of pelagic-benthic coupling? Deep-Sea Res II 55:2381-2389

* Morata N, Michaud E, Włodarska-Kowalczuk M (2015) Impact of early food input on the Arctic benthos activities during the polar night. Polar Biol 38:99-114

* Mundy CJ, Gosselin M, Ehn J, Gratton Y and others (2009) Contribution of under-ice primary production to an iceedge upwelling phytoplankton bloom in the Canadian Beaufort Sea. Geophys Res Lett 36:L17601

*Mundy CJ, Gosselin M, Gratton Y, Brown K and others (2014) Role of environmental factors on phytoplankton bloom initiation under landfast sea ice in Resolute Passage, Canada. Mar Ecol Prog Ser 497:39-49

Nishino S, Shimada K, Itoh M, Chiba S (2009) Vertical double silicate maxima in the sea-ice reduction region of the western Arctic Ocean: implications for an enhanced biological pump due to sea-ice reduction. J Oceanogr 65: 871-883

North CA, Lovvorn JR, Kolts JM, Brooks ML, Cooper LW, Grebmeier JM (2014) Deposit-feeder diets in the Bering 
Sea: potential effects of climatic loss of sea ice-related microalgal blooms. Ecol Appl 24:1525-1542

* Peterson BJ (1999) Stable isotopes as tracers of organic matter input and transfer in benthic food webs: a review. Acta Oecol 20:479-487

Piepenburg D (2005) Recent research on Arctic benthos: common notions need to be revised. Polar Biol 28: 733-755

Piepenburg D, Schmid MK (1996) Distribution, abundance, biomass, and mineralization potential of the epibenthic megafauna of the Northeast Greenland shelf. Mar Biol 125:321-332

* Piepenburg D, Blackburn TH, von Dorrien CF, Gutt J and others (1995) Partitioning of benthic community respiration in the Arctic (northwestern Barents Sea). Mar Ecol Prog Ser 118:199-213

Renaud PE, Morata N, Ambrose WG Jr, Bowie JJ, Chiuchiolo A (2007a) Carbon cycling by seafloor communities on the eastern Beaufort Sea shelf. J Exp Mar Biol Ecol 349: 248-260

Renaud PE, Riedel A, Michel C, Morata N, Gosselin M, JuulPedersen T, Chiuchiolo A (2007b) Seasonal variation in benthic community oxygen demand: a response to an ice algal bloom in the Beaufort Sea, Canadian Arctic? J Mar Syst 67:1-12

Renaud PE, Morata N, Carroll ML, Denisenko SG, Reigstad M (2008) Pelagic-benthic coupling in the western Barents Sea: processes and time scales. Deep-Sea Res II 55: 2372-2380

Rowe GT (1983) Biomass and production of the deep-sea macrobenthos. In: Rowe GT (ed) The sea. Wiley, New York, NY, p 97-121

Rowe GT, Boland GS, Escobar Briones EG, Cruz-Kaegi ME and others (1997) Sediment community biomass and respiration in the Northeast Water Polynya, Greenland: a numerical simulation of benthic lander and spade core data. J Mar Syst 10:497-515

Roy V, Iken K, Gosselin M, Tremblay JÉ, Bélanger S, Archambault P (2015) Benthic faunal assimilation pathways and depth-related changes in food-web structure across the Canadian Arctic. Deep-Sea Res I 102:55-71

Rutgers van der Loeff MM, Meyer R, Rudels B, Rachor E (2002) Resuspension and particle transport in the benthic nepheloid layer in and near Fram Strait in relation to faunal abundances and ${ }^{234}$ Th depletion. Deep-Sea Res I 49: 1941-1958

Rysgaard S, Thamdrup B, Risgaard-Petersen N, Fossing H, Berg P, Christensen PB, Dalsgaard T (1998) Seasonal carbon and nutrient mineralization in a high-Arctic coastal marine sediment, Young Sound, Northeast Greenland. Mar Ecol Prog Ser 175:261-276

Sameoto D, Herman A, Longhurst A (1986) Relations between the thermocline meso and microzooplankton, chlorophyll $a$ and primary production distributions in Lancaster Sound. Polar Biol 6:53-61

* Sampei M, Sasaki H, Hattori H, Fukuchi M, Hargrave BT (2004) Fate of sinking particles, especially fecal pellets, within the epipelagic zone in the North Water (NOW) polynya of northern Baffin Bay. Mar Ecol Prog Ser 278: $17-25$

Søreide JE, Leu E, Berge J, Graeve M, Falk-Petersen S (2010) Timing of blooms, algal food quality and Calanus glacialis reproduction and growth in a changing Arctic. Glob Change Biol 16:3154-3163
Sun MY, Carroll ML, Ambrose WG Jr, Clough LM, Zou L, Lopez GR (2007) Rapid consumption of phytoplankton and ice algae by Arctic soft-sediment benthic communities: evidence using natural and ${ }^{13} \mathrm{C}$-labeled food materials. J Mar Res 65:561-588

Sun MY, Clough LM, Carroll ML, Dai J, Ambrose WG, Lopez GR (2009) Different responses of two common Arctic macrobenthic species (Macoma balthica and Monoporeia affinis) to phytoplankton and ice algae: Will climate change impacts be species specific? J Exp Mar Biol Ecol 376:110-121

Kyvertsen EE (1991) Ice algae in the Barents Sea: types of assemblages, origin, fate and role in the ice-edge phytoplankton bloom. Polar Res 10:277-287

*Tamburini C, Garcin J, Bianchi A (2003) Role of deep-sea bacteria in organic matter mineralization and adaptation to hydrostatic pressure conditions in the NW Mediterranean Sea. Aquat Microb Ecol 32:209-218

* Tamelander T, Reigstad M, Hop H, Ratkova T (2009) Ice algal assemblages and vertical export of organic matter from sea ice in the Barents Sea and Nansen Basin (Arctic Ocean). Polar Biol 32:1261-1273

* Thomson DH (1982) Marine benthos in the eastern Canadian High Arctic: multivariate analyses of standing crop and community structure. Arctic 35:61-74

* Thornton B, Zhang Z, Mayes RW, Högberg MN, Midwood AJ (2011) Can gas chromatography combustion isotope ratio mass spectrometry be used to quantify organic compound abundance? Rapid Commun Mass Spectrom 25: 2433-2438

* Tremblay JÉ, Gratton Y, Fauchot J, Price NM (2002) Climatic and oceanic forcing of new, net, and diatom production in the North Water. Deep-Sea Res II 49:4927-4946

* Tremblay JÉ, Hattori H, Michel C, Ringuette M and others (2006) Trophic structure and pathways of biogenic carbon flow in the eastern North Water Polynya. Prog Oceanogr 71:402-425

* Tremblay JÉ, Robert D, Varela DE, Lovejoy C, Darnis G, Nelson RJ, Sastri AR (2012) Current state and trends in Canadian Arctic marine ecosystems: I. Primary production. Clim Change 115:161-178

* van Oevelen D, Bergmann M, Soetaert K, Bauerfeind E and others (2011) Carbon flows in the benthic food web at the deep-sea observatory HAUSGARTEN (Fram Strait). Deep-Sea Res I 58:1069-1083

*von Quillfeldt CH, Ambrose WG Jr, Clough LM, Ambrose WG (2003) High number of diatom species in first-year ice from the Chukchi Sea. Polar Biol 26:806-818

*Wang M, Overland JE (2015) Projected future duration of the sea-ice-free season in the Alaskan Arctic. Prog Oceanogr 136:50-59

*Wang SW, Budge SM, Gradinger RR, Iken K, Wooller MJ (2014) Fatty acid and stable isotope characteristics of sea ice and pelagic particulate organic matter in the Bering Sea: tools for estimating sea ice algal contribution to Arctic food web production. Oecologia 174:699-712

*Wassmann P, Reigstad M, Haug T, Rudels B and others (2006) Food webs and carbon flux in the Barents Sea. Prog Oceanogr 71:232-287

* Wassmann P, Carroll J, Bellerby RGJ (2008) Carbon flux and ecosystem feedback in the northern Barents Sea in an era of climate change: An introduction. Deep-Sea Res II 55:2143-2153

*Welch HE, Bergmann MA, Siferd TD, Martin KA and others 
(1992) Energy flow through the marine ecosystem of the Lancaster South Region, Arctic Canada. Arctic 45: 343-357

Werner K, Fritz M, Morata N, Keil K and others (2016) Arctic in rapid transition: priorities for the future of marine and coastal research in the Arctic. Polar Sci 10:364-373

White DC, Davis WM, Nickels JS, King JD, Bobbie RJ (1979) Determination of the sedimentary microbial biomass by extractible lipid phosphate. Oecologia 40:51-62

Witte U, Aberle N, Sand M, Wenzhöfer F (2003a) Rapid response of a deep-sea benthic community to POM enrichment: an in situ experimental study. Mar Ecol Prog Ser 251:27-36

Witte U, Wenzhöfer F, Sommer S, Boetius A and others (2003b) In situ experimental evidence of the fate of a

Editorial responsibility: Antonio Bode,

A Coruña, Spain phytodetritus pulse at the abyssal sea floor. Nature 424 : 763-766

*Wood KR, Bond NA, Danielson SL, Overland JE, Salo SA, Stabeno PJ, Whitefield J (2015) A decade of environmental change in the Pacific Arctic region. Prog Oceanogr 136:12-31

* Woulds C, Andersson JH, Cowie GL, Middelburg JJ, Levin LA (2009) The short-term fate of organic carbon in marine sediments: comparing the Pakistan margin to other regions. Deep-Sea Res II 56:393-402

Woulds C, Bouillon S, Cowie GL, Drake E, Middelburg JJ, Witte U (2016) Patterns of carbon processing at the seafloor: the role of faunal and microbial communities in moderating carbon flows. Biogeosciences 13: 4343-4357

Submitted: December 18, 2017; Accepted: June 7, 2018

Proofs received from author(s): July 24, 2018 